\title{
Review \\ Thermophysical Properties of Hybrid Nanofluids and the Proposed Models: An Updated Comprehensive Study
}

\author{
Mohammad M. Rashidi ${ }^{1, *}$, , Mohammad Alhuyi Nazari ${ }^{1}$, Ibrahim Mahariq ${ }^{2}{ }^{(0}$, Mamdouh El Haj Assad ${ }^{3}$, \\ Mohamed E. Ali ${ }^{4, *(1)}$, Redhwan Almuzaiqer ${ }^{4}$, Abdullah Nuhait ${ }^{4}$ and Nimer Murshid ${ }^{2}$ (i) \\ 1 Institute of Fundamental and Frontier Sciences, University of Electronic Science and Technology of China, \\ Chengdu 610054, China; m_Nazarii@uestc.edu.cn \\ 2 College of Engineering and Technology, American University of the Middle East, Kuwait; \\ Ibrahim.Maharik@aum.edu.kw (I.M.); nimer.murshid@aum.edu.kw (N.M.) \\ 3 Sustainable and Renewable Energy Engineering Department, University of Sharjah, Sharjah P.O. Box 27272, \\ United Arab Emirates; massad@sharjah.ac.ae \\ 4 Mechanical Engineering Department, College of Engineering, King Saud University, P.O. Box 800, \\ Riyadh 11421, Saudi Arabia; ralmuzaiqer@ksu.edu.sa (R.A.); anuhait@ksu.edu.sa (A.N.) \\ * Correspondence: mm_rashidi@uestc.edu.cn (M.M.R.); mali@ksu.edu.sa (M.E.A.)
}

check for updates

Citation: Rashidi, M.M.; Nazari, M.A.; Mahariq, I.; Assad, M.E.H.; Ali, M.E.; Almuzaiqer, R.; Nuhait, A.; Murshid, N. Thermophysical Properties of Hybrid Nanofluids and the Proposed Models: An Updated Comprehensive Study. Nanomaterials 2021, 11, 3084. https://doi.org/ 10.3390/nano11113084

Academic Editor: Manuel M. Piñeiro

Received: 24 September 2021

Accepted: 5 November 2021

Published: 16 November 2021

Publisher's Note: MDPI stays neutral with regard to jurisdictional claims in published maps and institutional affiliations.

Copyright: (C) 2021 by the authors. Licensee MDPI, Basel, Switzerland. This article is an open access article distributed under the terms and conditions of the Creative Commons Attribution (CC BY) license (https:/ / creativecommons.org/licenses/by/ $4.0 /)$.

\begin{abstract}
Thermal performance of energy conversion systems is one of the most important goals to improve the system's efficiency. Such thermal performance is strongly dependent on the thermophysical features of the applied fluids used in energy conversion systems. Thermal conductivity, specific heat in addition to dynamic viscosity are the properties that dramatically affect heat transfer characteristics. These features of hybrid nanofluids, as promising heat transfer fluids, are influenced by different constituents, including volume fraction, size of solid parts and temperature. In this article, the mentioned features of the nanofluids with hybrid nanostructures and the proposed models for these properties are reviewed. It is concluded that the increase in the volume fraction of solids causes improvement in thermal conductivity and dynamic viscosity, while the trend of variations in the specific heat depends on the base fluid. In addition, the increase in temperature increases the thermal conductivity while it decreases the dynamic viscosity. Moreover, as stated by the reviewed works, different approaches have applicability for modeling these properties with high accuracy, while intelligent algorithms, including artificial neural networks, are able to reach a higher precision compared with the correlations. In addition to the used method, some other factors, such as the model architecture, influence the reliability and exactness of the proposed models.
\end{abstract}

Keywords: hybrid nanostructures; thermophysical features; dynamic viscosity; thermal conductivity

\section{Introduction}

The heat transfer capacity of single-phase fluids, including water, oil and ethylene glycol, is relatively poor due to their low thermal conductivity. Since the intensification of heat transfer in industries and power plants is very important from both technical and economic points of view, a new generation of fluids with solid nanostructures has been recently applied. These fluids, known as nanofluids, are made of a base fluid and suspended solid particles, sheets or tubes in nano dimensions [1]. There are different approaches for the preparation of nanofluids. Physical methods, such as ball milling and ultrasonication, in addition to chemical processes, such as functionalization, are among the main approaches used for the preparation of nanofluids [2]. Metal oxide particles, such as $\mathrm{CuO}, \mathrm{Al}_{2} \mathrm{O}_{3}, \mathrm{TiO}_{2}$ in addition to the carbonic materials, including Carbon Nano Tubes (CNTs), graphene and graphite, are among the most commonly used nanostructures in the nanofluids that are applied as heat transfer fluids [3,4]. By applying functionalization, it would be possible to modify some properties of CNTs, such as solubility, that makes them more dispersible in the base fluid [2]. The dispersion of solid materials with nanometer 
dimensions in the fluid can modify their heat transfer properties [5]. Improvement in these properties is dependent on different factors that are considered in various researches [6-8]. Regarding the improved heat transfer characteristics of nanofluids, they can be applied to enhance the performance of various systems, such as thermoelectric generator modules and heat exchangers [9-11]. In addition to the single type nanostructures, two or more dissimilar nanomaterials could be added to the base fluid, which leads to the preparation of hybrid nanofluids [12]. The idea of employing hybrid nanofluids is to achieve more enhancement in thermal characteristics and pressure drop by a trade-off between the disadvantages and advantages of an individual nanostructure, which is attributed to a more proper thermal network, appropriate aspect ratio and synergistic impact of nanostructures [13]. In other words, hybrid materials simultaneously combine the chemical and physical properties of two or more materials that provide these specifications in a homogenous phase [13]. These properties may not be obtained in the case of using an individual nanomaterial. Several studies have shown that hybrid nanofluids have improved thermophysical properties in comparison to the nanofluids containing a single material; however, some of the studies have reported that the thermal conductivity of hybrid nanofluids is lower than conventional ones, which is mainly attributed to the non-compatibility of the materials with each other, inappropriate size of the nanostructures, stability of the nanofluid and temperature of the fluid [14]. In this regard, to prepare a hybrid nanofluid with desirable properties, it is crucial to consider different factors. Similar to mono nanofluids, different approaches are applicable for the synthesis and preparation of hybrid nanofluids, which are dependent on the properties of the composites and required stability.

Hybrid nanofluids, due to their modified thermal characteristics, have been tested in numerous thermal engineering applications [15-18]. For instance, Hussein et al. [19] applied a hybrid nanofluid composed of covalent functionalized multi-walled carbon nanotubes (MWCNTs) and covalently functionalized graphene nanoplatelets in a flat plate solar collector. They observed that utilizing the hybrid nanofluid in a collector caused around $20 \%$ higher efficiency of the system in comparison with the case of using distilled water. Fattahi [20] investigated the performance of a hybrid nanofluid in a solar collector and concluded that up to $23 \%$ improvement in the heat transfer was possible by employing the nanofluid. Asokan et al. [21] investigated the effect of using nanofluids containing $\mathrm{CuO}$, $\mathrm{Al}_{2} \mathrm{O}_{3}$ and their hybrid particles in a compact heat exchanger. They found that applying the hybrid nanofluids caused better enhancement in the performance compared with the mono nanofluids. Pandya et al. [22] charged an axial grooved heat pipe with a hybrid nanofluid composed of $\mathrm{CeO}_{2}$-MWCNT and observed that using this working fluid led to $30 \%$ lower thermal resistance compared with the case of using water as the working fluid. Aside from the abovementioned applications, using hybrid nanofluids in other types of thermal mediums, such as pulsating heat pipes, could result in the improvement of performance [23].

Among thermophysical properties of fluids, thermal conductivity, specific heat and dynamic viscosity play key roles in their heat transfer characteristics. Although there are some review articles on the thermophysical properties of nanofluids, there are few works that consider both the properties and the proposed models. In addition, the majority of the review papers have focused on one or two properties of nanofluids, mainly TC and DV, while specific heat is another property that influences the heat transfer characteristics of nanofluidic flow. In this regard, the present work focuses on all of the mentioned properties of hybrid nanofluids as promising heat transfer fluids. Compared with other studies on similar topics, the present work is updated and considers all of the recently published documents. In the following sections, studies on these thermophysical properties and the corresponding models are reviewed. Furthermore, some recommendations are proposed for the upcoming studies in the related research. 


\section{Methodology}

As mentioned in the introduction section, heat transfer characteristics of nanofluids are significantly affected by three thermophysical properties, including thermal conductivity, dynamic viscosity and specific heat. The aim of the present paper is to review the factors affecting these features and the proposed models used for predicting and estimating these properties of nanofluids. In this regard, different search engines, including SCOPUS, Google Scholar and EBSCO, and other sources, such as the websites of publishers, including MDPI, ELSEVIER, Wiley, Taylor \& Francis, Springer Nature, ASME and OXFORD, were applied to search the keywords. The main keywords used for the search were "Hybrid Nanofluids", "Thermal Conductivity", "Dynamic Viscosity", "Specific Heat", "Machine Learning" and "Artificial Neural Network". In the first step, to find the sources for the properties of the nanofluids, Boolean AND was used to join "Hybrid Nanofluid" with one of the following keywords, including "Dynamic Viscosity", "Thermal Conductivity", "Specific Heat". Afterward, Boolean AND was used to join other keywords. Other keywords that were used for the studies on the forecasting and prediction of these nanofluids were "Modeling", "Artificial Intelligence", "Neural Network" and "Machine Learning". In this case, Boolean OR was applied to find all of the works on the mentioned properties. All documents published between 1990 and 2021 were considered for evaluation. It should be mentioned that just English documents were used for the review. The first inclusion criterion for the consideration of the sources for review was the consideration of hybrid nanofluids for investigation. The second inclusion criterion was the consideration of one of the three mentioned thermophysical properties. The exclusion criteria consisted of all of the studies that did not meet the mentioned criteria. It should be mentioned that review papers were considered for the introduction section. Both experimental and numerical works were considered for the present work in order to provide a comprehensive study. Afterward, two of the authors checked the gathered documents independently to select the appropriate ones. They considered the abovementioned criteria to include the proper documents for the current review.

In cases where there was disagreement between the referees, a third one was asked to finalize the decision. Subsequently, the authors categorized the documents on the basis of the properties. In this regard, the selected documents were divided into three main groups, including thermal conductivity, dynamic viscosity and specific heat. Afterward, the categorized documents for each property were divided into two groups, including the models and measurement. Subsequently, the main findings of the selected documents were summarized to be reflected in the current article.

The most important questions to be answered in this review paper are as follows:

- Which factors affect the thermophysical properties of the hybrid nanofluids?

- How do the influential factors affect the properties of hybrid nanofluids?

- How can we model and forecast the thermophysical properties of hybrid nanofluids?

- Which factors influence the accuracy of the models used for the properties of the hybrid nanofluids?

- How can we improve the exactness of the proposed models?

\section{Thermal Conductivity}

Thermal conductivity (TC) of the fluids plays a crucial role in their heat transfer ability; in this regard, it is desirable to utilize fluids with higher thermal conductivity. The dispersion of hybrid solids in nanometer dimensions can notably improve the TC owing to the Brownian motion, intermolecular interaction of the nanostructures, higher TC of solids compared with the liquids and clustering of the nanostructures [24-28]. The enhancement rate of hybrid nanofluid TC depends on some factors, such as the temperature and volume fraction (VF) [29-34]. For instance, Esfe et al. [35] measured the TC of a hybrid nanofluid composed of $\mathrm{SiO}_{2}-\mathrm{MWCNT}$ and ethylene glycol (EG) at different temperatures and VFs of the solid phase. They found that the increase in the temperature and solid VF caused an increase in the thermal conductivity ratio (TCR). They found that in the considered 
ranges of VF $(0.05-1.95 \%)$ and temperature $\left(30-50{ }^{\circ} \mathrm{C}\right)$, the highest value of the increase in TCR was $22.2 \%$, as shown in Figure 1. The increase in the TC with temperature is mainly attributed to the Brownian motions of the nanostructures, while increases in the TC with VF are mainly due to higher TC of the solid materials compared with the base fluids. In another work [36], the influences of temperature and VF on the $\mathrm{TC}$ of $\mathrm{WO}_{3}$ MWCNT/engine oil were investigated. The ranges of VF and temperature were $0.05-0.6 \%$ and $20-60^{\circ} \mathrm{C}$, respectively. It was found that despite the increase in the TC by increasing VF and temperature, the effect of VF was more notable. The highest enhancement in the TC of the investigated hybrid nanofluid was $19.85 \%$ compared with the base fluid that was obtained at the highest temperature and VF. Higher enhancement in the TC of hybrid nanofluids has been observed by using other nanostructures. Utilizing hybrid material containing carbonic-based materials, such as graphene, graphite and CNTs, can lead to significant enhancement in the TC. As an example, Kazemi et al. [37] measured the TC of graphene- $\mathrm{SiO}_{2}$ /water in various conditions. As shown in Figure 2, it was observed that around $36 \%$ enhancement in TC was reachable at $50{ }^{\circ} \mathrm{C}$ and VF of $1 \%$. Esfe et al. [38] measured TC of $\mathrm{SiO}_{2}$-DWCNT/EG in various temperature and VF ranges of $30-50{ }^{\circ} \mathrm{C}$ and $0.03-1.71 \%$, respectively. The highest improvement in the TC of nanofluid compared with EG as the base fluid was 38\%. In another study, Pourrajab et al. [39] found that the existence of $0.04 \%$ vol and $0.16 \%$ vol MWCNT in water could improve the TC by up to $47.3 \%$ compared with water as the base fluid. Trinh et al. [40] measured the TC of Gr-CNT/EG nanofluid at different temperatures and observed that it was enhanced by $50 \%$ at $50{ }^{\circ} \mathrm{C}$ in solid VF of $0.07 \%$.

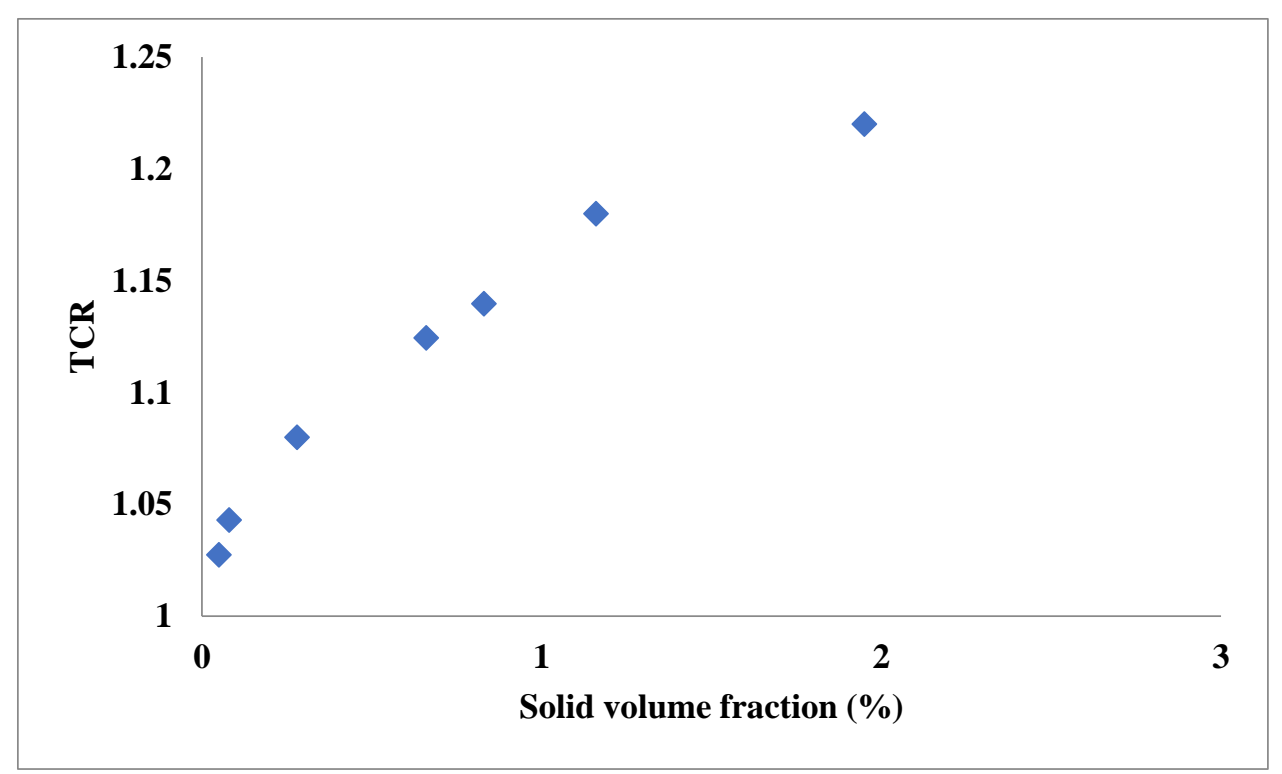

Figure 1. Effect of solid VF and temperature on TCR of $\mathrm{SiO}_{2}-\mathrm{MWCNT}(85: 15 \%) / \mathrm{EG}$. Adapted from Ref. [35].

Aside from the temperature and VF of solid parts, other factors are involved in the TC enhancement of hybrid nanofluids. As an example, Dalkılıç et al. [41] measured the TC of $\mathrm{CNT}-\mathrm{SiO}_{2}$ / water nanofluid under different conditions. In addition to the temperature and VF of nanostructures, the mass ratio of solid structures was varied to investigate its effect on TC. It was noticed that the highest enhancement of TC obtained for VF of $1 \%$, and mass ratio of $0.8 \mathrm{CNT}$ and $0.2 \mathrm{SiO}_{2}$ and was equal to $26.29 \%$, while the minimum enhancement was noticed for $0.1 \% \mathrm{VF}$ and $0.2 \mathrm{CNT}$ and $0.8 \mathrm{SiO}_{2}$ that was equal to $0.78 \%$. In another work, impacts of other variables, such as sonication duration and surfactant on the TC of a hybrid $\mathrm{CeO}_{2}-\mathrm{MWCNT} /$ water nanofluid, were investigated by Tiwari et al. [42]. They found that there was an optimal sonication time to reach the maximum TCR. Furthermore, they noticed that the surfactant could influence the TC, as shown in Figure 3. The mixture ratio, 
indicating the ratio of the nanomaterials in the hybrid nanofluids, can remarkably influence the thermophysical properties. Different mixture ratios, depending on the properties of each nanomaterial, can affect the TC of hybrid nanofluids. For instance, Osho et al. [43] considered mixture ratios in addition to VF and temperature in measuring the TC of a hybrid nanofluid. The mixture ratios of the nanostructure composed of both $\mathrm{Al}_{2} \mathrm{O}_{3}$ and $\mathrm{ZnO}$ were 1:2, 1:1 and 2:1. The maximum improvement in the TC was observed for a mixture ratio of $2: 1\left(\mathrm{Al}_{2} \mathrm{O}_{3}: \mathrm{ZnO}\right)$, which was equal to $40 \%$ for a $\mathrm{VF}$ of $1.67 \%$.

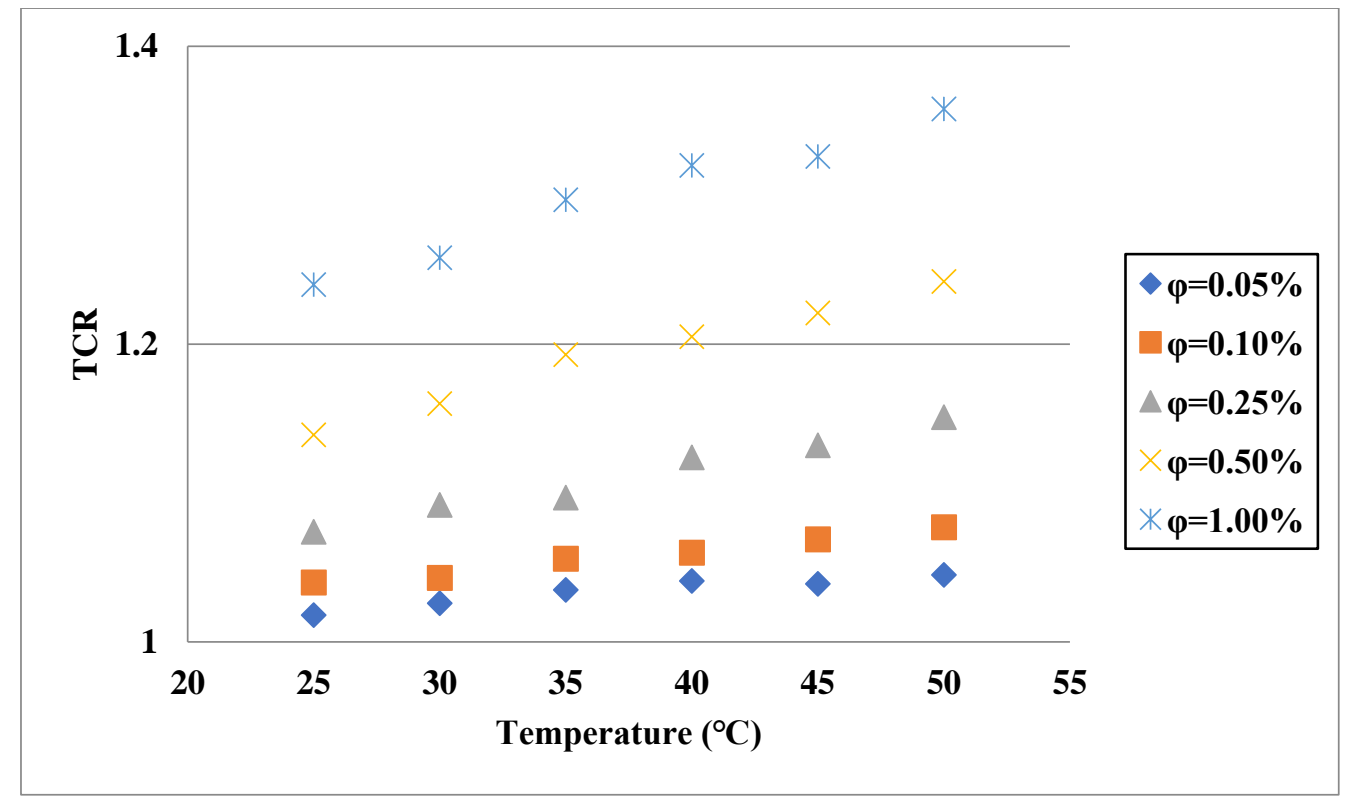

Figure 2. TCR and the enhancement in TC for different VFs. Adapted from Ref. [37].

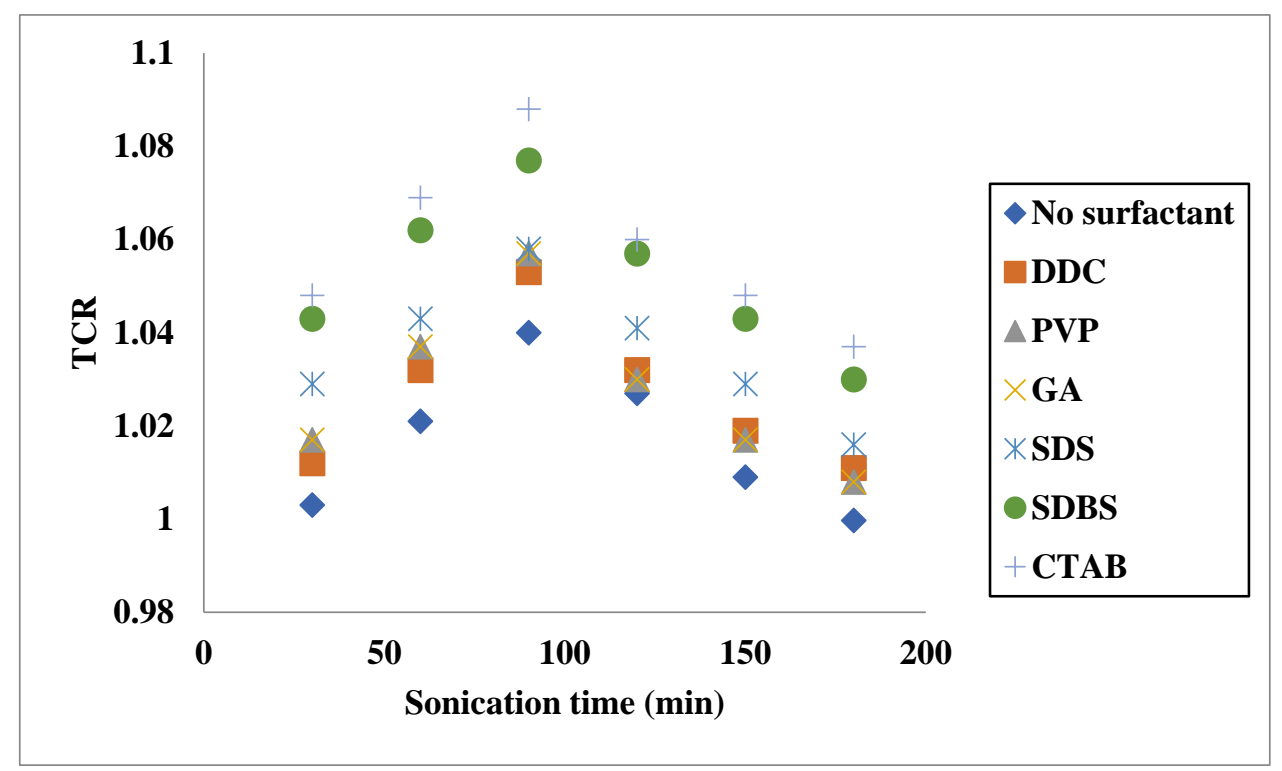

Figure 3. Effects of surfactant and sonication time on TCR of $\mathrm{CeO}_{2}-\mathrm{MWCNT} /$ water (SMR: surfactant mixing ratio $=3: 2, \varphi=0.75 \%, \mathrm{~T}=30^{\circ} \mathrm{C}$ ). Adapted from Ref. [42].

Aside from the single base fluid, a solution of two or more fluids could be applied as the base fluid of hybrid nanofluids [44-47]. The dispersion of hybrid nanostructures in these types of fluids leads to TC enhancement [48]. Esfe et al. [49] assessed the influences of both concentration and temperature on the TC of a hybrid nanofluid composed of Single-Walled Carbon Nanotube (SWCNT)-ZnO and EG-water as the base fluid. Similar to 
the hybrid nanofluids with a single base fluid, they found that TCR increased by increases of the temperature and VF of solid structures, as shown in Figure 4. In addition, according to the sensitivity analysis, it was deduced that the sensitivity of TC enhancement was more remarkable to VF compared with the temperature. In another work [50], the TC of a nanofluid composed of $\mathrm{SiO}_{2}-\mathrm{TiO}_{2}$ nanostructures in water-EG was investigated. It was noticed that TCR had higher values in cases of increasing both temperature and solid fraction, and its value could exceed 1.2 at the highest VF and temperature, as shown in Figure 5. In another work [51], the TC of antifreeze-based nanofluid (Go-CuO/EGwater) was measured under different conditions by varying the temperature and VF of solids. Similar to the previously mentioned works, they found that TCR increased by increasing the $\mathrm{VF}$ and temperature. In the maximum considered temperature and VF, $50{ }^{\circ} \mathrm{C}$ and $1.6 \%$, respectively, the TCR exceeded 1.4. In another research carried out by Esfe et al. [52], the TC of MWCNT-MgO/water-EG nanofluid was investigated in the temperature and concentration ranges of $30-50{ }^{\circ} \mathrm{C}$ and $0.015-0.96 \%$, respectively. Despite the low concentrations of the nanostructures, around a $22 \%$ improvement in the TC was observed at the maximum temperature and concentration. This noticeable enhancement in the TC by adding the hybrid nanostructures is mainly due to the higher TC of the solid phase compared with the binary base fluid.

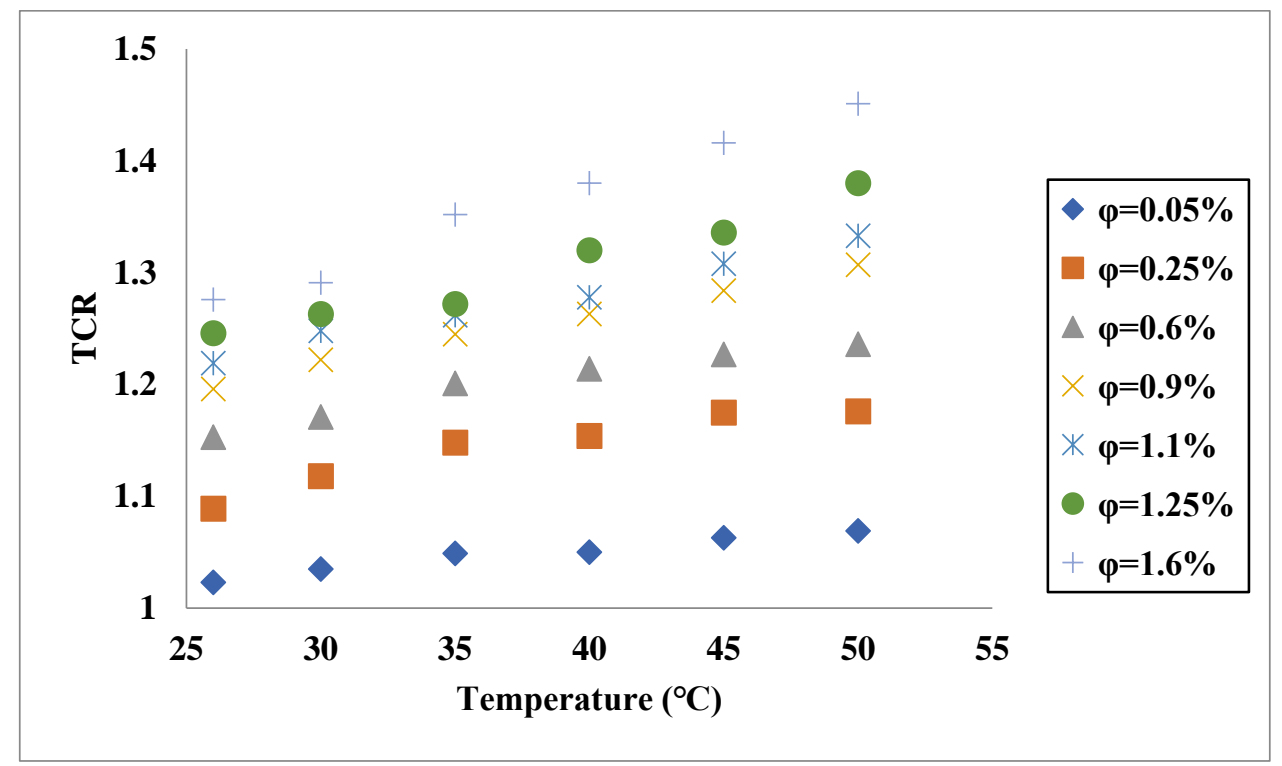

Figure 4. Influences of temperature and VF on TCR of SWCNT-ZnO/EG-water. Adapted from Ref. [49].

Hybrid nanofluids are not restricted to the ones containing two dissimilar materials. Cakmak et al. [53] prepared a hybrid nanofluid composed of three materials as nanostructures, including reduced graphene oxide (rGO), $\mathrm{Fe}_{3} \mathrm{O}_{4}$ and $\mathrm{TiO}_{2}$ and $\mathrm{EG}$ as the base fluid. The ranges of concentrations and temperatures considered in their study were $0.01-0.25 \%$ mass and $25-60{ }^{\circ} \mathrm{C}$, respectively. An improvement of $13.3 \%$ in the TC at temperature and concentration of $60^{\circ} \mathrm{C}$ and $0.25 \%$ wt was observed compared with EG. In another work [54], the TC of a ternary hybrid nanofluid, $\mathrm{MWCNT}-\mathrm{TiO}_{2}-\mathrm{ZnO} /$ water-EG, was measured in temperature and VF ranges of $25-50{ }^{\circ} \mathrm{C}$ and $0.1-0.4 \%$, respectively. At the maximum temperature and $\mathrm{VF}$, the TC enhancement was around $10 \%$. In Table 1, the works on the hybrid nanofluids' TC are summarized. 


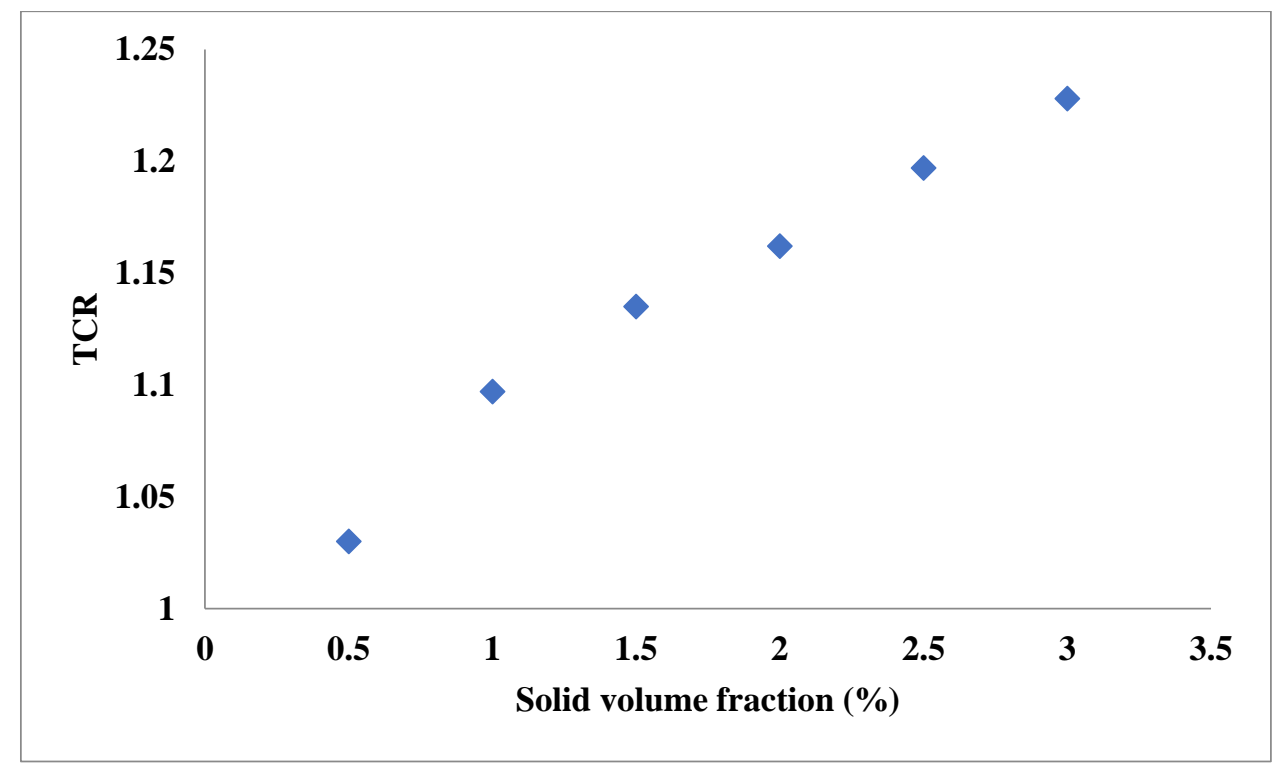

Figure 5. TCR of $\mathrm{SiO}_{2}-\mathrm{TiO}_{2} /$ water-EG for different temperatures and $\mathrm{VFs}$ and $\mathrm{T}=80^{\circ} \mathrm{C}$. Adapted from Ref. [50].

Table 1. Findings of the works on the TC of hybrid nanofluids.

\begin{tabular}{|c|c|c|c|}
\hline Reference & Nanostructures & Base Fluid & Important Findings \\
\hline Akhgar et al. [46] & $\mathrm{TiO}_{2}-\mathrm{MWCNT}$ & Water-EG & $\begin{array}{l}\text { Up to } 38.7 \% \text { enhancement in TC at temperature and VF } \\
\text { of } 50{ }^{\circ} \mathrm{C} \text { and } 1 \% \text {, respectively. }\end{array}$ \\
\hline Aparna Z. et al. [25] & $\mathrm{Al}_{2} \mathrm{O}_{3}-\mathrm{Ag}$ & Water & $\begin{array}{l}\text { Compared with water, up to } 23.82 \% \text { enhancement in the } \\
\text { TC of nanofluid was observed at temperature of } 325 \mathrm{~K} \text {. }\end{array}$ \\
\hline Esfe et al. [27] & MWCNT-SiO 2 & EG & $\begin{array}{l}\text { Up to } 20.1 \% \text { enhancement in the TC of nanofluid } \\
\text { compared with EG. }\end{array}$ \\
\hline Esfahani et al. [28] & $\mathrm{ZnO}-\mathrm{Ag}$ & Water & $\begin{array}{l}\text { TCR of the nanofluid was higher than } 1.25 \text { at } \\
\text { temperature of } 50{ }^{\circ} \mathrm{C} \text { and VF of } 2 \% \text {. }\end{array}$ \\
\hline Toghraie et al. [32] & $\mathrm{ZnO}-\mathrm{TiO}_{2}$ & EG & $\begin{array}{c}\text { Up to } 32 \% \text { improvement in } \mathrm{TC} \text { at temperature of } 50{ }^{\circ} \mathrm{C} \\
\text { and VF of } 3.5 \% \text {. }\end{array}$ \\
\hline Esfe et al. [31] & SWCNT- $\mathrm{Al}_{2} \mathrm{O}_{3}$ & EG & $\begin{array}{l}\text { Up to } 41.2 \% \text { enhancement in TC at temperature of } 50{ }^{\circ} \mathrm{C} \\
\text { and VF of } 2.5 \% .\end{array}$ \\
\hline Zadkhast et al. [33] & MWCNT-CuO & Water & $\begin{array}{l}\text { Up to } 30.38 \% \text { enhancement in TC at temperature and VF } \\
\text { of } 50{ }^{\circ} \mathrm{C} \text { and } 0.6 \% \text {, respectively. }\end{array}$ \\
\hline Esfe et al. [34] & SWCNT-MgO & EG & $\begin{array}{l}\text { More than } 35 \% \text { enhancement in TC at temperature and } \\
\text { VF of } 50{ }^{\circ} \mathrm{C} \text { and } 0.55 \% \text {, respectively. }\end{array}$ \\
\hline Bakhtiari et al. [26] & $\mathrm{TiO}_{2}-\mathrm{Gr}$ & Water & $\begin{array}{l}\text { Up to } 27.84 \% \text { increase in TC was observed in } 75^{\circ} \mathrm{C} \text { and } \\
\text { VF of } 0.5 \% .\end{array}$ \\
\hline Taherialekouhi et al. [29] & GO- $\mathrm{Al}_{2} \mathrm{O}_{3}$ & Water & $\begin{array}{l}\text { TC of nanofluid increases by up to } 33.9 \% \text { in case of } \\
\text { existence of the nanostructures. }\end{array}$ \\
\hline Esfe et al. [35] & $\mathrm{SiO}_{2}-\mathrm{MWCNT}$ & EG & $\begin{array}{l}\text { Increase in temperature and VF of solid phase brings } \\
\text { out higher thermal conductivity ratio. }\end{array}$ \\
\hline Esfe et al. [38] & $\mathrm{SiO}_{2}-\mathrm{DWCNT}$ & EG & Up to $38 \%$ improvement in TC compared with EG. \\
\hline Singh et al. [30] & $\mathrm{Go}-\mathrm{CuO}$ & Distilled water & $\begin{array}{c}30 \% \text { enhancement in } \mathrm{TC} \text { at } 60^{\circ} \mathrm{C} \text { and } \\
0.3 \% \text { wt concentration. }\end{array}$ \\
\hline Soltani et al. [36] & $\mathrm{WO}_{3}-\mathrm{MWCNT}$ & Engine oil & $\begin{array}{l}\text { Maximum increase in TC was } 19.85 \% \text { compared with } \\
\text { the base fluid. }\end{array}$ \\
\hline Pourrajab et al. [39] & Ag-MWCNT & Water & $\begin{array}{c}\text { By dispersing the nanostructures, up to } 47.3 \% \\
\text { improvement in TC was reachable. }\end{array}$ \\
\hline
\end{tabular}


Table 1. Cont.

\begin{tabular}{|c|c|c|c|}
\hline Reference & Nanostructures & Base Fluid & Important Findings \\
\hline Dalkılıç et al. [41] & $\mathrm{CNT}-\mathrm{SiO}_{2}$ & Water & $\begin{array}{l}\text { Mixture ratio of solid components affects the TC } \\
\text { enhancement of the nanofluid. }\end{array}$ \\
\hline Moghadam et al. [55] & $\mathrm{GO}-\mathrm{TiO}_{2}$ & Water & Maximum enhancement of TC was $32.8 \%$. \\
\hline Tiwari et al. [42] & $\mathrm{CeO}_{2}-\mathrm{MWCNT}$ & Water & $\begin{array}{l}\text { Surfactant and sonication time affect TCR of the } \\
\text { hybrid nanofluid. }\end{array}$ \\
\hline Trinh et al. [40] & Gr-CNT & EG & $\begin{array}{l}\text { Up to } 50 \% \text { TC improvement compared with the base } \\
\text { fluid in } 0.07 \% \text { VF. }\end{array}$ \\
\hline Esfe et al. [48] & $\mathrm{Cu}-\mathrm{TiO}_{2}$ & Water-EG & TCR exceeds 1.4 at $60^{\circ} \mathrm{C}$ and $\mathrm{VF}$ of $2 \%$. \\
\hline Kakavandi et al. [44] & MWCNT-SiC & Water-EG & $\begin{array}{l}\text { Up to } 33 \% \text { increase in the TC of nanofluid at } \\
\text { temperature equal to } 50{ }^{\circ} \mathrm{C} \text { and VF of } 0.75 \% \text {. }\end{array}$ \\
\hline Wole-Osho et al. [43] & $\mathrm{Al}_{2} \mathrm{O}_{3}-\mathrm{ZnO}$ & Water & $\begin{array}{l}\text { Mixture ratio of } 2: 1\left(\mathrm{Al}_{2} \mathrm{O}_{3}: \mathrm{ZnO}\right) \text { leads to the highest } \\
\text { TC compared with 1:2 and 1:1. }\end{array}$ \\
\hline Esfe et al. [49] & SWCNT-ZnO & EG-water & $\begin{array}{l}\text { Sensitivity of TC to the VF was more notable compared } \\
\text { with temperature. }\end{array}$ \\
\hline Esfe et al. [52] & MWCNT-MgO & Water-EG & $\begin{array}{l}\text { Around } 22 \% \text { enhancement in TC was observed at } \\
\text { temperature and VF of } 50{ }^{\circ} \mathrm{C} \text { and } 0.96 \% \text {. }\end{array}$ \\
\hline Leong et al. [47] & $\mathrm{Cu}-\mathrm{TiO}_{2}$ & EG-water & Up to $9.8 \%$ enhancement in TC in mass fraction of $0.8 \%$. \\
\hline Rostamian et al. [45] & CuO-SWCNT & EG-water & $\begin{array}{l}\text { Around } 35 \% \text { enhancement in TC at temperature equal to } \\
\qquad 50^{\circ} \mathrm{C} \text { and VF of } 0.75 \% \text {. }\end{array}$ \\
\hline Esfe et al. [37] & graphene- $\mathrm{SiO}_{2}$ & Water & $\begin{array}{c}\text { Around } 36 \% \text { enhancement in the TC was achievable in } \\
\text { temperature of } 50{ }^{\circ} \mathrm{C} \text { and VF of } 1 \% \text {. }\end{array}$ \\
\hline Nabil et al. [50] & $\mathrm{SiO}_{2}-\mathrm{TiO}_{2}$ & Water-EG & $\begin{array}{l}\text { TCR can exceed } 1.2 \text { at the maximum considered } \\
\text { temperature and VF. }\end{array}$ \\
\hline Rostami et al. [51] & $\mathrm{Go}-\mathrm{CuO}$ & EG-water & $\begin{array}{l}\text { At the highest temperature and solid VF, TCR } \\
\text { exceeds 1.4. }\end{array}$ \\
\hline Moradi et al. [56] & $\mathrm{TiO}_{2}-\mathrm{MWCNT}$ & EG-water & $\begin{array}{l}\text { Around } 34 \% \text { enhancement in TC at temperature of } \\
\qquad 60^{\circ} \mathrm{C} \text { and VF of } 1 \% .\end{array}$ \\
\hline Cakmak et al. [53] & $\mathrm{rGO}-\mathrm{Fe}_{3} \mathrm{O}_{4}-\mathrm{TiO}_{2}$ & EG & $\begin{array}{l}\text { Around } 13 \% \text { enhancement in TC at temperature of } \\
60{ }^{\circ} \mathrm{C} \text { and mass concentration of } 0.25 \% \text {. }\end{array}$ \\
\hline Boroomandpour et al. [54] & $\begin{array}{l}\mathrm{MWCNT}-\mathrm{TiO}_{2}- \\
\mathrm{ZnO}\end{array}$ & Water-EG & $\begin{array}{l}\text { Around } 10 \% \text { enhancement in } \mathrm{TC} \text { at the maximum } \\
\text { considered temperature and VF. }\end{array}$ \\
\hline
\end{tabular}

\section{Proposed Models for Thermal Conductivity}

Different techniques are employable to estimate the characteristics of hybrid nanofluids. In several studies, mathematical correlations have been used to estimate hybrid nanofluids' TC with relatively high precision and reliability. Taherialekouhi et al. [29] proposed a correlation based on the VF of hybrid structures and temperature to model the TCR of a hybrid nanofluid composed of $\mathrm{GO}-\mathrm{Al}_{2} \mathrm{O}_{3}$ and water. The ranges of concentration and temperature were $0.1-1 \%$ and $25-50{ }^{\circ} \mathrm{C}$, respectively. The highest deviation of the model was $1.598 \%$, showing remarkable accuracy. In another work, the TCR of $\mathrm{CNT}^{-\mathrm{SiO}_{2}} /$ water nanofluid in different temperatures, concentrations and mass fractions of solid materials were modeled by considering all of these variables. The maximum deviation of their model, based on the correlation, was 8.3\%. In another research, Esfe et al. [34] applied a correlation for the TCR of EG-based nanofluid containing SWCNT-MgO nanostructures with an R-squared value of around 0.993 .

Despite the advantage of correlation in terms of simplicity to use, the exactness of these models is relatively lower compared with the models based on intelligent techniques, including artificial neural networks (ANNs). By using artificial intelligent methods, models with improved exactness can be developed due to the more complex structure of these 
networks. These models are generally developed on the basis of simulating the processes of human intelligence by machines. Models based on artificial intelligence are applicable for different purposes related to nanofluids. By these methods, it is possible to model the heat transfer of nanofluidic flows, the performance of the systems utilizing nanofluids and the properties of the fluids containing nanomaterials. In modeling with intelligent methods, it is crucial to consider some factors, including the architecture of the model, input and functions, to reach the outputs with the highest possible accuracy.

Esfe et al. [35] evaluated the performance of a correlation and ANN in modeling the TCR of $\mathrm{SiO}_{2}-\mathrm{MWCNT} / \mathrm{EG}$ and observed that the R-squared of the indicated models were equal to 0.9864 and 0.9981 , respectively. In another work [49], correlation and ANN were compared in modeling the TCR of SWCNT-ZnO/EG-water. The obtained values of R-squared for the mentioned models were 0.9918 and 0.9972 , respectively. Efficiency of the ANNs in modeling is dependent on different elements, such as applied function and the network architecture. In this regard, to propose an ANN-based model with the highest accuracy in predicting the TC of hybrid nanofluids, testing different architectures and functions would be useful. In a work performed by Vafaei et al. [57], 6, 8, 10 and 12 neurons were tested in the hidden layer (HL) of the applied network proposed for TC modeling of MgO-MWCNT/EG nanofluid. They found that using 12 neurons led to a minimum error, and the predicted data were nearer to the corresponding experimental quantities in comparison with the networks with other numbers of neurons. Aside from the number of neurons, applied functions and the number of HL influence the exactness and performance of ANN-based models. Safaei et al. [58] tested different architectures to find the best network for modeling the $\mathrm{TC}$ of $\mathrm{ZnO}-\mathrm{TiO}_{2} / \mathrm{EG}$ nanofluid. They found that the most accurate model was obtained using 2 HLs with six and five neurons in the first and second layers, respectively, where the transfer functions in these layers were tan-sig and log-sig, respectively. In addition to the architecture, applied optimization methods in the ANN-based models affect the exactness of the models. Alarifi et al. [59] applied two optimization approaches, GA and PSO, in the models based on ANFIS used for TC of $\mathrm{Al}_{2} \mathrm{O}_{3}-\mathrm{MWCNT} /$ oil. They found that employing the ANFIS-PSO model led to a lower value of the mean square error compared with ANFIS-GA, which means that by using the PSO algorithm as the optimization approach, the hyperparameters of the models, which significantly affect the error of the predicted values, could be obtained more properly.

Similar to the hybrid nanofluids with a single base fluid, several models have been proposed for the hybrid ones with base fluids composed of two or more fluids. As an example, Nabil et al. [50] proposed a correlation to model TCR of $\mathrm{SiO}_{2}-\mathrm{TiO}_{2} / \mathrm{EG}$-water. The highest value of deviation between the obtained data by correlation and experimental measurement was around $4.6 \%$, showing acceptable exactness of the correlation. In another work, Kakavandi et al. [44] proposed a correlation for the TC modeling of MWCNT$\mathrm{SiC} /$ water EG with a maximum deviation of $1.58 \%$. Rostami et al. [51] applied both correlation and ANN to model the TCR of a hybrid nanofluid composed of binary base fluid (Go-CuO/EG-water). They found that applying ANN led to closer prediction to the experimental values, as was expected, due to its more complex structure and estimation procedures compared with the correlation. In a work done by Akhgar et al. [24], correlation and ANN with different numbers of neurons in HL in range the of 6-31 were tested for modeling the TC of $\mathrm{MWCNT}^{-\mathrm{TiO}_{2}}$ / water-EG nanofluid by considering temperature and VF in the inputs. They found that utilizing eight neurons in the HL led to the network with the highest accuracy, with the maximum error of $2.1 \%$, while the highest error in the case of applying the correlation was $2.72 \%$. In another research [48], the $\mathrm{TC}$ of $\mathrm{Cu}-\mathrm{TiO}_{2} /$ water-EG nanofluid was modeled by applying different architectures of ANN. One and two HLs were tested with the 1 to 10 neurons in each layer. They observed that using two layers with five neurons in each one resulted in the highest exactness, with an MSE of $2.62 \times 10^{-5}$. Since the utilization of more hidden layers enables the network to model the complex systems with higher accuracy, this finding was expected; however, in the case of using more hidden layers, the possibility of overfitting is increased. 
There are some models that are applicable for more than one nanofluid. In these cases, it is necessary to consider more inputs compared with the models used for a single case of hybrid nanofluids. In a study by Pourrajab et al. [60], different methods were used to propose models for the TC of hybrid nanofluids with water, EG and the mixture of water and EG as the base fluids. In their work, Locally Weighted Linear Regression (LWLR), Linear Genetic Programming (LGP), Gene Expression Programming (GEP) and some empirical correlations were used for comparison. Aside from temperature and $\mathrm{VF}$, which are commonly used in other studies, the density of materials, their mean size and TC and mixture ratio of water and EG were used as inputs. Root Mean Squared Error (RMSE) of training datasets for the proposed models by LWLR, LGP and GEP were $0.011,0.0279$ and 0.044 , respectively. These RMSE values demonstrated higher exactness of the model based on LWLR compared with the others. Considering the effect of the mixture ratio on the TC of hybrid nanofluids, it must be used as one of the inputs in the cases where a model is developed for various mixture ratios. For instance, in [43] different approaches were used to propose a model for $\mathrm{TC}$ of $\mathrm{Al}_{2} \mathrm{O}_{3}-\mathrm{ZnO} /$ water nanofluid in different temperatures, VFs and mixture ratios of the nanostructures. They used ANN, ANFIS and correlation for this purpose and found that applying ANFIS resulted in the highest accuracy. In a work performed by Jamei et al. [61], three methods, including genetic programming (GP), multilinear regression (MLR) and model tree (MT), were used to predict the TC of EG-based hybrid nanofluids. In their models, besides temperature and VF, the sizes of particles in addition to their densities were utilized as inputs. Among the used methods, GP led to the best performance that was followed by MT and MLR, respectively. Table 2 demonstrates the models provided for the TC of hybrid nanofluids.

Table 2. Proposed models for TC of hybrid nanofluids.

\begin{tabular}{|c|c|c|c|c|}
\hline Reference & Nanostructures & Base Fluid & Method & Important Findings \\
\hline Aparna Z. et al. [25] & $\mathrm{Al}_{2} \mathrm{O}_{3}-\mathrm{Ag}$ & Water & Correlation & $\begin{array}{l}\text { R-squared of the proposed } \\
\text { correlation was } 0.9748 .\end{array}$ \\
\hline Bakhtiari et al. [26] & $\mathrm{TiO}_{2}-\mathrm{Gr}$ & Water & Correlation & Margin error of the model was $1.44 \%$. \\
\hline Moghadam et al. [55] & $\mathrm{GO}-\mathrm{TiO}_{2}$ & Water & Correlation & $\begin{array}{l}\text { The correlation was able to model TC } \\
\text { with acceptable exactness. }\end{array}$ \\
\hline Taherialekouhi et al. [29] & $\mathrm{GO}-\mathrm{Al}_{2} \mathrm{O}_{3}$ & Water & Correlation & $\begin{array}{l}\text { The model highest } \\
\text { deviation was } 1.598 \% \text {. }\end{array}$ \\
\hline Esfe et al. [34] & SWCNT-MgO & EG & Correlation & $\begin{array}{l}\text { R-squared of the proposed } \\
\text { correlation was around } 0.993 \text {. }\end{array}$ \\
\hline Toghraie et al. [32] & $\mathrm{ZnO}-\mathrm{TiO}_{2}$ & EG & Correlation & The model highest deviation was $1.74 \%$. \\
\hline Moradi et al. [56] & $\mathrm{TiO}_{2}-\mathrm{MWCNT}$ & EG-water & Correlation & The model highest deviation was $2.72 \%$. \\
\hline Zadkhast et al. [33] & MWCNT-CuO & Water & Correlation & $\begin{array}{l}\text { TCR of the nanofluid was predicted } \\
\text { with acceptable accuracy by using the } \\
\text { proposed correlation. }\end{array}$ \\
\hline Esfahani et al. [28] & $\mathrm{ZnO}-\mathrm{Ag}$ & Water & Correlation & $\begin{array}{c}\text { Deviation margin } \\
\text { of the model was } 1.3 \% \text {. }\end{array}$ \\
\hline Esfe et al. [31] & $\mathrm{SWCNT}-\mathrm{Al}_{2} \mathrm{O}_{3}$ & EG & $\begin{array}{l}\text { Correlation and } \\
\text { ANN }\end{array}$ & $\begin{array}{l}\text { Maximum deviations of the models by } \\
\text { applying correlation and ANN were } \\
2.6 \% \text { and } 1.94 \% \text {, respectively. }\end{array}$ \\
\hline Safaei et al. [58] & $\mathrm{ZnO}-\mathrm{TiO}_{2}$ & EG & $\begin{array}{l}\text { Correlation and } \\
\text { ANN }\end{array}$ & $\begin{array}{l}\text { ANN-based model with optimal } \\
\text { geometry had much higher accuracy } \\
\text { compared with the correlation. }\end{array}$ \\
\hline Esfe et al. [27] & MWCNT-SiO 2 & EG & $\begin{array}{l}\text { Correlation and } \\
\text { ANN }\end{array}$ & $\begin{array}{c}\text { Using two HLs with four neurons in } \\
\text { each layer led to the highest exactness of } \\
\text { the ANN-based model } \\
\text { with R-squared of } 0.9989 \text {. }\end{array}$ \\
\hline
\end{tabular}


Table 2. Cont.

\begin{tabular}{|c|c|c|c|c|}
\hline Reference & Nanostructures & Base Fluid & Method & Important Findings \\
\hline Dalkılıç et al. [41] & $\mathrm{CNT}-\mathrm{SiO}_{2}$ & Water & Correlation & The model highest deviation was $8.3 \%$. \\
\hline Esfe et al. [35] & $\mathrm{SiO}_{2}-\mathrm{MWCNT}$ & EG & $\begin{array}{l}\text { Correlation and } \\
\text { ANN }\end{array}$ & $\begin{array}{l}\text { R-squared of the models by using } \\
\text { correlation and ANN were } 0.9864 \text { and } \\
0.9981 \text {, respectively. }\end{array}$ \\
\hline Esfe et al. [38] & $\mathrm{SiO}_{2}-\mathrm{DWCNT}$ & EG & $\begin{array}{l}\text { Correlation and } \\
\text { ANN }\end{array}$ & $\begin{array}{l}\text { The number of HL, applied functions } \\
\text { and number of neurons affect the } \\
\text { exactness of the ANN-based model. }\end{array}$ \\
\hline Esfe et al. [48] & $\mathrm{Cu}-\mathrm{TiO}_{2}$ & Water-EG & $\begin{array}{l}\text { Correlation and } \\
\text { ANN }\end{array}$ & $\begin{array}{l}\text { MSE values of the correlation and } \\
\text { optimum ANN were } 1.33 \times 10^{-4} \text { and } \\
2.62 \times 10^{-5} \text {, respectively. }\end{array}$ \\
\hline Esfe et al. [49] & SWCNT-ZnO & EG-water & $\begin{array}{l}\text { Correlation and } \\
\text { ANN }\end{array}$ & $\begin{array}{l}\text { R-squared of the models on the basis of } \\
\text { correlation and ANN were } 0.9918 \text { and } \\
0.9972 \text {, respectively. }\end{array}$ \\
\hline Esfe et al. [37] & graphene- $\mathrm{SiO}_{2}$ & Water & Correlation & R-squared of the model was 0.99. \\
\hline Pourrajab et al. [39] & Ag-MWCNT & Water & Correlation & R-squared of the model was 0.992. \\
\hline Kakavandi et al. [44] & MWCNT-SiC & Water-EG & Correlation & $\begin{array}{l}\text { The maximum deviation of } \\
\text { the model was } 1.58 \% \text {. }\end{array}$ \\
\hline Vafaei et al. [57] & MgO-MWCNT & EG & $\begin{array}{l}\text { Correlation and } \\
\text { ANN }\end{array}$ & $\begin{array}{c}\text { Using } 12 \text { neurons in the HL of the } \\
\text { network leads to higher accuracy } \\
\text { compared with the cases of utilizing } 6,8 \\
\text { and } 10 \text { neurons. }\end{array}$ \\
\hline Alarifi et al. [59] & $\mathrm{Al}_{2} \mathrm{O}_{3}-\mathrm{MWCNT}$ & Oil & $\begin{array}{l}\text { ANFIS-PSO and } \\
\text { ANFIS-GA }\end{array}$ & $\begin{array}{c}\text { Using ANFIS-PSO led to higher } \\
\text { accuracy compared with ANFIS-GA. }\end{array}$ \\
\hline Nabil et al. [50] & $\mathrm{SiO}_{2}-\mathrm{TiO}_{2}$ & Water-EG & Correlation & Maximum deviation was lower than $5 \%$ \\
\hline Rostamian et al. [45] & CuO-SWCNT & EG-water & $\begin{array}{l}\text { Correlation and } \\
\text { ANN }\end{array}$ & $\begin{array}{l}\text { Maximum deviation in case of applying } \\
\text { ANN was } 0.544 \% \text {. }\end{array}$ \\
\hline Akhgar et al. [24] & $\mathrm{MWCNT}^{-\mathrm{TiO}_{2}}$ & Water-EG & $\begin{array}{l}\text { Correlation and } \\
\text { ANN }\end{array}$ & $\begin{array}{c}\text { Using ANN in optimal architecture led } \\
\text { to maximum error of } 2.1 \% \text { while this } \\
\text { value was } 2.72 \% \\
\text { when correlation was applied. }\end{array}$ \\
\hline Akhgar et al. [46] & $\mathrm{TiO}_{2}-\mathrm{MWCNT}$ & Water-EG & Two correlations & $\begin{array}{l}\text { R-squared of the proposed correlations } \\
\text { in modeling TC of the } \\
\text { nanofluid was around } 0.99 .\end{array}$ \\
\hline Pourrajab et al. [60] & $\begin{array}{l}\text { Different hybrid } \\
\text { nanostructures }\end{array}$ & $\begin{array}{l}\text { Water, EG and } \\
\text { different } \\
\text { mixture of } \\
\text { these fluids }\end{array}$ & $\begin{array}{l}\text { LWLR, LGP and } \\
\text { GEP }\end{array}$ & $\begin{array}{l}\text { Using LWLR leads to the model with } \\
\text { the highest accuracy. }\end{array}$ \\
\hline Wole-Osho et al. [43] & $\mathrm{Al}_{2} \mathrm{O}_{3}-\mathrm{ZnO}$ & Water & $\begin{array}{l}\text { Correlation, ANN } \\
\text { and ANFIS }\end{array}$ & $\begin{array}{l}\text { Using ANFIS for modeling led to the } \\
\text { highest accuracy. }\end{array}$ \\
\hline Rostami et al. [51] & $\mathrm{Go}-\mathrm{CuO}$ & EG-water & $\begin{array}{l}\text { Correlation and } \\
\text { ANN }\end{array}$ & $\begin{array}{l}\text { Compared with the correlation, } \\
\text { applying ANN leads to higher accuracy. }\end{array}$ \\
\hline Cakmak et al. [53] & $\mathrm{rGO}-\mathrm{Fe}_{3} \mathrm{O}_{4}-\mathrm{TiO}_{2}$ & EG & Correlation & $\begin{array}{l}\text { Depending on the temperature, } \\
\text { R-squared of the proposed model was in } \\
\text { range of } 0.954 \text { and } 0.99 \text {. }\end{array}$ \\
\hline Jamei et al. [61] & $\begin{array}{c}\text { Different } \\
\text { nanostructures }\end{array}$ & EG & GP, MT and MLR & $\begin{array}{l}\text { Using GP led to the highest accuracy } \\
\text { followed by MT and MLR. }\end{array}$ \\
\hline
\end{tabular}




\section{Specific Heat}

Another thermophysical property of the fluids affecting their heat transfer is specific heat capacity. Similar to the TC, specific heat $(\mathrm{SH})$ is influenced by several factors. In a study conducted by Çolak et al. [62], the $\mathrm{SH}$ of $\mathrm{Cu}-\mathrm{Al}_{2} \mathrm{O}_{3} /$ water nanofluid was investigated at different temperatures and VFs of solids in ranges of $20-65^{\circ} \mathrm{C}$ and $0.01255-0.2 \%$, respectively. As illustrated in Figure 6, the SH gradually increased by increasing the temperature, while the increase in the solid VF reduced the SH. In another work [63], the effects of these parameters on the $\mathrm{SH}$ were investigated for a $\mathrm{MgO}^{-\mathrm{TiO}_{2}} /$ distilled water hybrid nanofluid. As shown in Figure 7, the increase in temperature reduces the $\mathrm{SH}$ to their minimum values, while a further increase in temperature causes an increase in the SH. Similar to the previously mentioned nanofluid, the increase in solid VF results in lower SH in all temperatures. The trend of variations in the $\mathrm{SH}$ of the nanofluids in different concentrations was similar to the base fluid since it is the main component of the nanofluid. Gao et al. [64] experimentally investigated the $\mathrm{SH}$ of $\mathrm{GO}-\mathrm{Al}_{2} \mathrm{O}_{3}$ / water nanofluid and observed that a higher solid fraction caused more reduction in the $\mathrm{SH}$. The highest reduction ratio in the $\mathrm{SH}$ was observed at the lowest temperature $\left(20^{\circ} \mathrm{C}\right)$ and the highest mass fraction of solids $(0.15 \% \mathrm{wt})$, which was equal to $7 \%$. More reduction at a higher concentration can be attributed to the lower $\mathrm{SH}$ of solid materials in comparison with the liquids used as the base fluid.

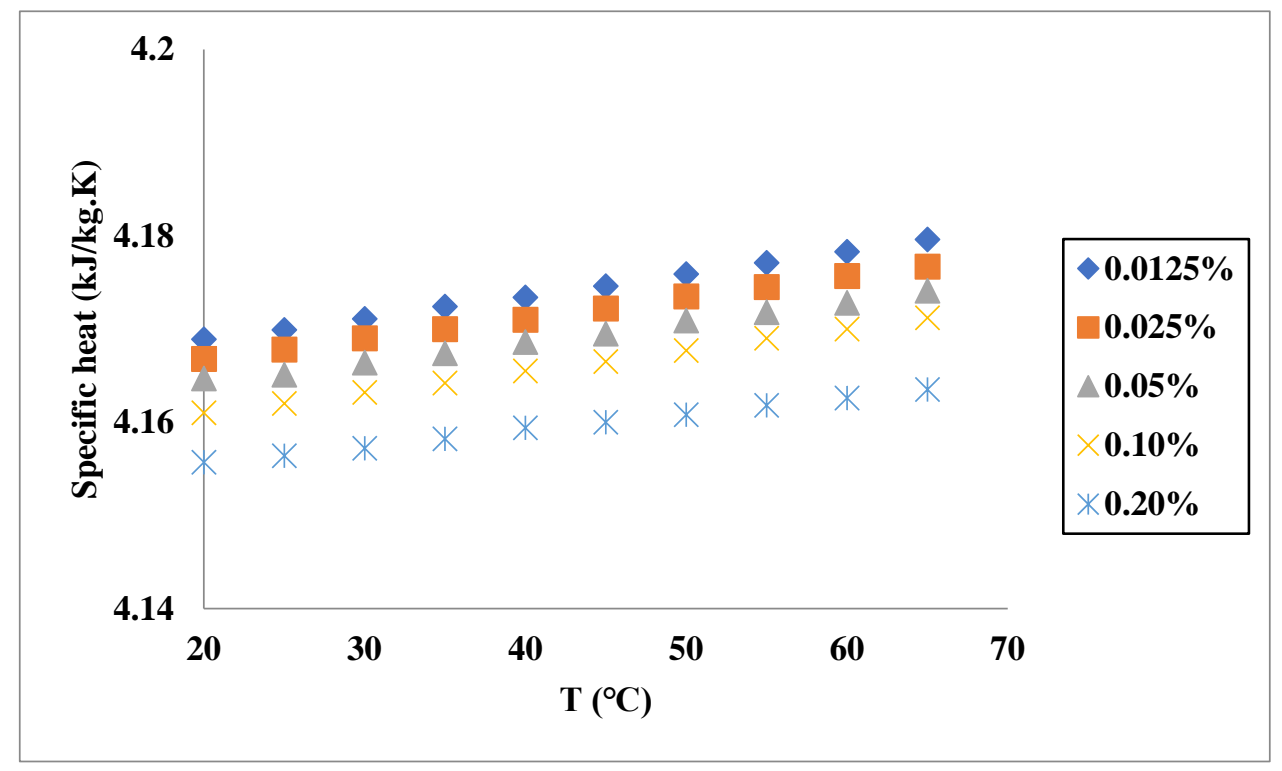

Figure 6. $\mathrm{SH}$ variation with temperature of $\mathrm{Cu}-\mathrm{Al}_{2} \mathrm{O}_{3} /$ water for different solid fractions. Adapted from Ref. [62].

Aside from temperature and solid fraction, other factors, such as the size of particles and their types, influence the reduction in SH. For instance, Tiwari et al. [65] measured the $\mathrm{SH}$ of different hybrid nanofluids, including CuO-MWCNT/water, MgO-MWCNT/water and $\mathrm{SnO}_{2}-\mathrm{MWCNT} /$ water, in different solid fractions, temperature and sizes of metal oxide particles ( 20 to $50 \mathrm{~nm}$ ). They observed that in cases of the lower size of particles, a higher decrease in the SH occurred, which was attributed to the reduction in the density of the nanofluids due to the increase in particles size. The highest reduction in the $\mathrm{SH}$ of the nanofluids was $15.09 \%$ at a temperature of $25^{\circ} \mathrm{C}$ and a mean size of $20 \mathrm{~nm}$.

In addition to the nanofluids with two dissimilar nanomaterials, the $\mathrm{SH}$ of ternary hybrid nanofluids with three nanomaterials has been investigated. In a study conducted by Mousavi et al. [66], the $\mathrm{SH}$ of a ternary hybrid nanofluid with various mass ratios of the particles $\mathrm{CuO}-\mathrm{MgO}-\mathrm{TiO}_{2}$ was measured. The mass ratios of the particles were (A: 33.4\%:33.3\%:33.3\%, B: 50\%:25\%:25\%, C: $60 \%: 30 \%: 10 \%$, D: $25 \%: 50 \%: 25 \%$ and E: $25 \%: 25 \%: 50 \%$ ). The considered VF and temperature were $0.1-0.5 \%$ and $15-60{ }^{\circ} \mathrm{C}$, respectively. The measured values of the SH revealed that it had a reducing trend up to $35^{\circ} \mathrm{C}$, afterward it 
had an increasing trend by increasing the temperature. The maximum decrease in the $\mathrm{SH}$ of the nanofluids was noticed for the $\mathrm{C}$ type. Consequently, it was concluded that the material specifications of the nanostructures influenced the $\mathrm{SH}$ of the hybrid nanofluid. The influence of the materials on the $\mathrm{SH}$ of the hybrid nanofluids has been observed in other studies [67]. Table 3 summarizes the works on the SH of hybrid nanofluids.

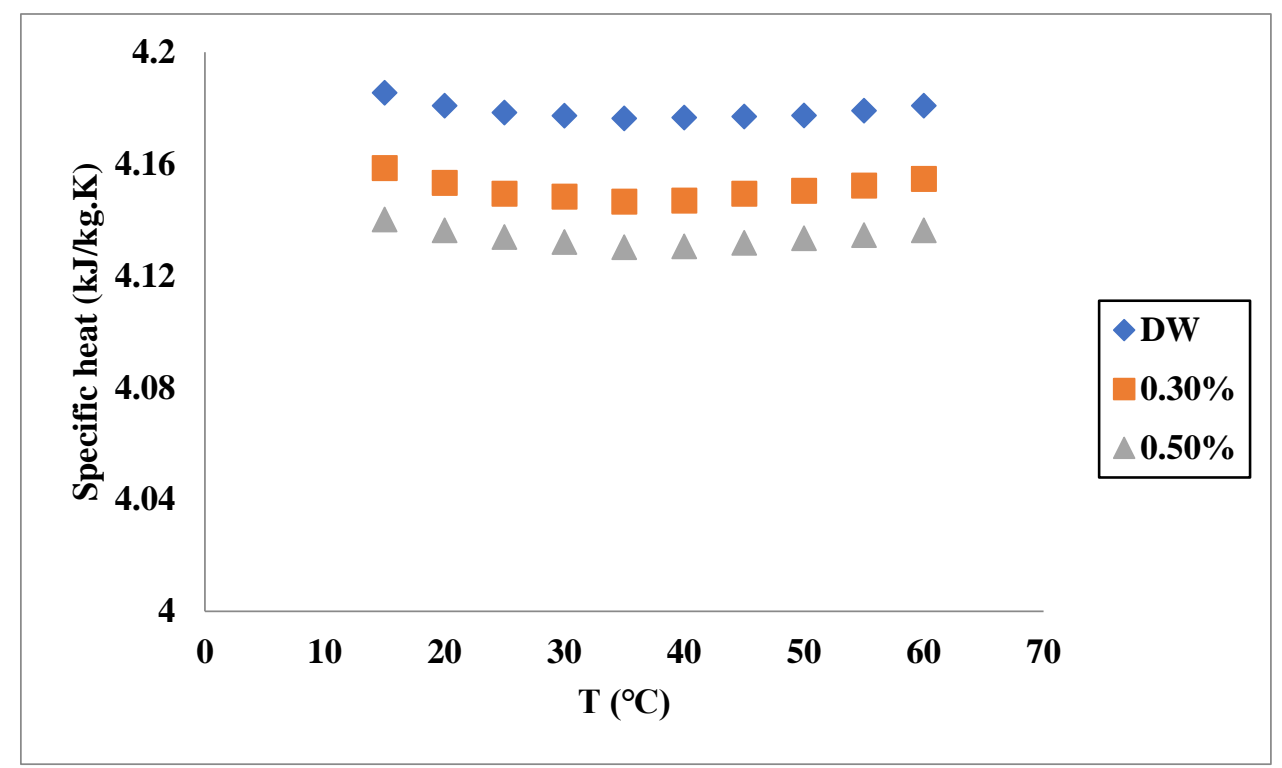

Figure 7. $\mathrm{SH}$ variation with temperature of $\mathrm{MgO}-\mathrm{TiO}_{2} /$ distilled water for different solid fractions. Adapted from Ref. [63].

Table 3. Findings of the works on the SH of hybrid nanofluids.

\begin{tabular}{|c|c|c|c|}
\hline Reference & Nanostructures & Base Fluid & Important Findings \\
\hline Çolak et al. [62] & $\mathrm{Cu}-\mathrm{Al}_{2} \mathrm{O}_{3}$ & Water & $\begin{array}{l}\text { Reduction in SH of the hybrid nanofluid was } \\
\text { noticed by an increase in the solid VF. }\end{array}$ \\
\hline Mousavi et al. [63] & $\mathrm{MgO}-\mathrm{TiO}_{2}$ & Water & $\begin{array}{l}\text { Increase in temperature reduced the } \mathrm{SH} \text { to } \\
\text { their minimum values while further increase } \\
\text { leads to increase in } \mathrm{SH} \text {. }\end{array}$ \\
\hline Gao et al. [64] & $\mathrm{GO}-\mathrm{Al}_{2} \mathrm{O}_{3}$ & Water & $\begin{array}{c}\text { Up to } 7 \% \text { reduction ratio in } \mathrm{SH} \text { of the } \\
\text { nanofluid at temperature of } 20{ }^{\circ} \mathrm{C} \text { and mass } \\
\text { fraction of } 0.15 \% \text {. }\end{array}$ \\
\hline Tiwari et al. [65] & $\begin{array}{l}\text { CuO-MWCNT, } \\
\text { MgO-MWCNT and } \\
\mathrm{SnO}_{2}-\mathrm{MWCNT}\end{array}$ & Water & $\begin{array}{l}\text { Higher reduction in the } \mathrm{SH} \text { was observed in } \\
\text { lower sizes of metal oxide particles. }\end{array}$ \\
\hline Mousavi et al. [66] & $\mathrm{CuO}-\mathrm{MgO}-\mathrm{TiO}_{2}$ & Water & $\begin{array}{l}\text { Mass fraction ratio of the nanostructures } \\
\text { affects SH of the hybrid nanofluid. }\end{array}$ \\
\hline Moldoveanu et al. [67] & $\begin{array}{l}\mathrm{Al}_{2} \mathrm{O}_{3}-\mathrm{TiO}_{2} \text { and } \\
\mathrm{Al}_{2} \mathrm{O}_{3}-\mathrm{Si}_{2} \mathrm{O}_{3}\end{array}$ & Water & $\begin{array}{l}\text { Dispersion of } \mathrm{Al}_{2} \mathrm{O}_{3}-\mathrm{TiO}_{2} \text { in the base fluid led } \\
\text { to higher reduction in the } \mathrm{SH} \text {. }\end{array}$ \\
\hline
\end{tabular}

Proposed Models for Specific Heat

Compared with the TC and dynamic viscosity, there are few works on the modeling of SH. This property of the hybrid nanofluids has been modeled and predicted by different techniques, such as correlation, support vector machines and ANN [68-70]. For instance, Mousavi et al. [63] proposed a correlation for $\mathrm{SH}$ of $\mathrm{MgO}-\mathrm{TiO}_{2} /$ water and found the model reliable since its R-squared was 0.993. Çolak et al. [62] used both correlation and ANN to model the $\mathrm{SH}$ of $\mathrm{Cu}-\mathrm{Al}_{2} \mathrm{O}_{3} /$ water by using temperature and solid fraction. They found that using ANN provided a model with a much lower relative error. Similar to TC, lower errors 
of the model based on ANN for predicting the SH are mainly due to its more complex structure and determination procedures.

There are some models with improved comprehensiveness that are applicable for more than one nanofluid. For instance, Tiwari et al. [65] proposed a correlation by considering the density, size and SH of nanoparticles besides temperature and VF for SH modeling of three different nanofluids, including CuO-MWCNT/water, MgO-MWCNT/water and $\mathrm{SnO}_{2}-\mathrm{MWCNT} /$ water. The maximum error of their model was $2.93 \%$, while the average absolute relative error was $0.903 \%$, demonstrating the high exactness of the model. In another work [67], a correlation was proposed to model the $\mathrm{SH}$ of water-based hybrid nanofluids containing $\mathrm{Al}_{2} \mathrm{O}_{3}-\mathrm{TiO}_{2}$ and $\mathrm{Al}_{2} \mathrm{O}_{3}-\mathrm{Si}_{2} \mathrm{O}_{3}$ for different temperatures and $\mathrm{VFs}$. In their correlation, densities of water and nanostructure in addition to size and concentration were used for regression; however, the model was not very accurate, and the average deviation was $11 \%$, and they concluded that to reach an accurate prediction, it would be preferred not to use the unified model. In Table 4, the results of the works on SH estimation of hybrid nanofluids are provided.

Table 4. Proposed models for the SH of hybrid nanofluids.

\begin{tabular}{|c|c|c|c|c|}
\hline Reference & Nanostructures & Base Fluid & Method & Important Findings \\
\hline Çolak et al. [62] & $\mathrm{Cu}-\mathrm{Al}_{2} \mathrm{O}_{3}$ & Water & Correlation and ANN & $\begin{array}{l}\text { ANN provided a model with } \\
\text { much lower relative error } \\
\text { compared with the correlation. }\end{array}$ \\
\hline Mousavi et al. [63] & $\mathrm{MgO}-\mathrm{TiO}_{2}$ & Water & Correlation & $\begin{array}{l}\text { R-squared of the } \\
\text { correlation was } 0.993 \text {. }\end{array}$ \\
\hline Tiwari et al. [65] & $\begin{array}{l}\mathrm{CuO}-\mathrm{MWCNT} \\
\mathrm{MgO}-\mathrm{MWCNT} \text { and } \\
\mathrm{SnO}_{2}-\mathrm{MWCNT}\end{array}$ & Water & Correlation & $\begin{array}{c}\text { The maximum deviation of } \\
\text { their model was } 2.93 \% \text {. }\end{array}$ \\
\hline Mousavi et al. [66] & $\mathrm{CuO}-\mathrm{MgO}-\mathrm{TiO}_{2}$ & Water & Correlation & $\begin{array}{c}\text { The deviation of the model } \\
\text { was around } 1 \% \text {. }\end{array}$ \\
\hline Moldoveanu et al. [67] & $\begin{array}{c}\mathrm{Al}_{2} \mathrm{O}_{3}-\mathrm{TiO}_{2} \text { and } \\
\mathrm{Al}_{2} \mathrm{O}_{3}-\mathrm{Si}_{2} \mathrm{O}_{3}\end{array}$ & Water & Correlation & The average deviation was $11 \%$. \\
\hline
\end{tabular}

\section{Dynamic Viscosity}

Dynamic viscosity (DV) is an important property of heat transfer fluid that affects the fluid heat transfer characteristics. Generally, nanoparticles suspension in the liquid increases the fluid DV, which is a function of different factors [71-75]. In a study done by Motahari et al. [76], the impacts of the solid fraction and temperature on the DV of MWCNT$\mathrm{SiO}_{2} / 20 \mathrm{~W} 50$ oil were assessed. The considered solid fraction and temperature ranges in their work were $0.05-1 \%$ and $40-100{ }^{\circ} \mathrm{C}$, respectively. They found that at the highest temperature and solid fraction, DV increased up to $171 \%$ compared with the base fluid. In another work [77], the DV of graphene- $\mathrm{NiO} /$ coconut oil was investigated in different solid fractions and temperatures. Similar to the previous study [76], it was observed that DV increased by increasing the solid fraction while it decreased by increasing the temperature. The enhancement in the DV of the nanofluid at a temperature of $120^{\circ} \mathrm{C}$ and solid weight fraction of $0.5 \%$ was $28.49 \%$. In addition to the abovementioned factors, the material of the nanostructures can affect the DV of the hybrid nanofluids. As an example, Ghaffarkhah et al. [78] investigated the DV of oil-based hybrid nanofluids with various

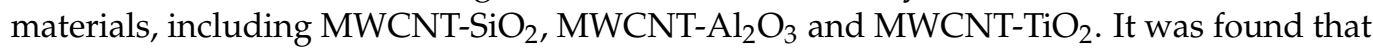
the impact of the material was very low, and the maximum improvements in the DV of the hybrid nanofluids with the mentioned materials were $13.015 \%, 13.618 \%$ and $12.559 \%$, respectively. However, in a work by Dalk1liç et al. [79] on the $\mathrm{DV}$ of $\mathrm{SiO}_{2}$-graphite/water, it was found that $\mathrm{SiO}_{2}$ particles had more effect on the DV compared with graphite. The maximum increase in the DV was $36.12 \%$, which was obtained for a solid fraction of $2 \%$. 
The surfactant of the hybrid nanofluids and their concentration influence the DV. $\mathrm{Ma}$ et al. [80] investigated the impacts of surfactant on the DV of $\mathrm{Al}_{2} \mathrm{O}_{3}-\mathrm{TiO}_{2} /$ water and $\mathrm{Al}_{2} \mathrm{O}_{3}-\mathrm{CuO} /$ water nanofluids and found that the increase in the PVP, used as a surfactant, led to the enhancement in the DV of the nanofluid. In addition, it was noticed that an increase in the concentration of the surfactant to more than $0.02 \% \mathrm{wt}$ caused a significant increase in the DV.

The DV of hybrid nanofluids with the base fluids composed of two liquids has been considered in some works. For instance, Urmi et al. [81] carried out a study on the DV of $\mathrm{TiO}_{2}-\mathrm{Al}_{2} \mathrm{O}_{3} /$ water-EG nanofluids considering the impacts of solid fraction and temperature. As shown in Figure 8, similar to single base fluid hybrid nanofluids, the DV increased by increasing the VF and decreased by increasing the temperature. The highest value of relative DV was observed at a temperature of $80^{\circ} \mathrm{C}$ and a VF of $0.1 \%$, which was equal to $161.8 \%$. In another work [82], the DV of $\mathrm{Al}_{2} \mathrm{O}_{3}-\mathrm{CuO} / \mathrm{EG}$-water and $\mathrm{Al}_{2} \mathrm{O}_{3}-\mathrm{CuO} /$ propylene glycol (PG) was measured in the temperature range of $50-70{ }^{\circ} \mathrm{C}$ and solid VF of $0-1.5 \%$. Moreover, the mixture ratio of the base fluid was varied to investigate its effect. It was observed that the increase in the fraction of nanostructures, EG and PG, led to higher DV of the hybrid nanofluids; however, at a temperature of $70{ }^{\circ} \mathrm{C}$, the increase in the fraction of EG from $50 \%$ to $55 \%$ led to lower dynamic viscosity.

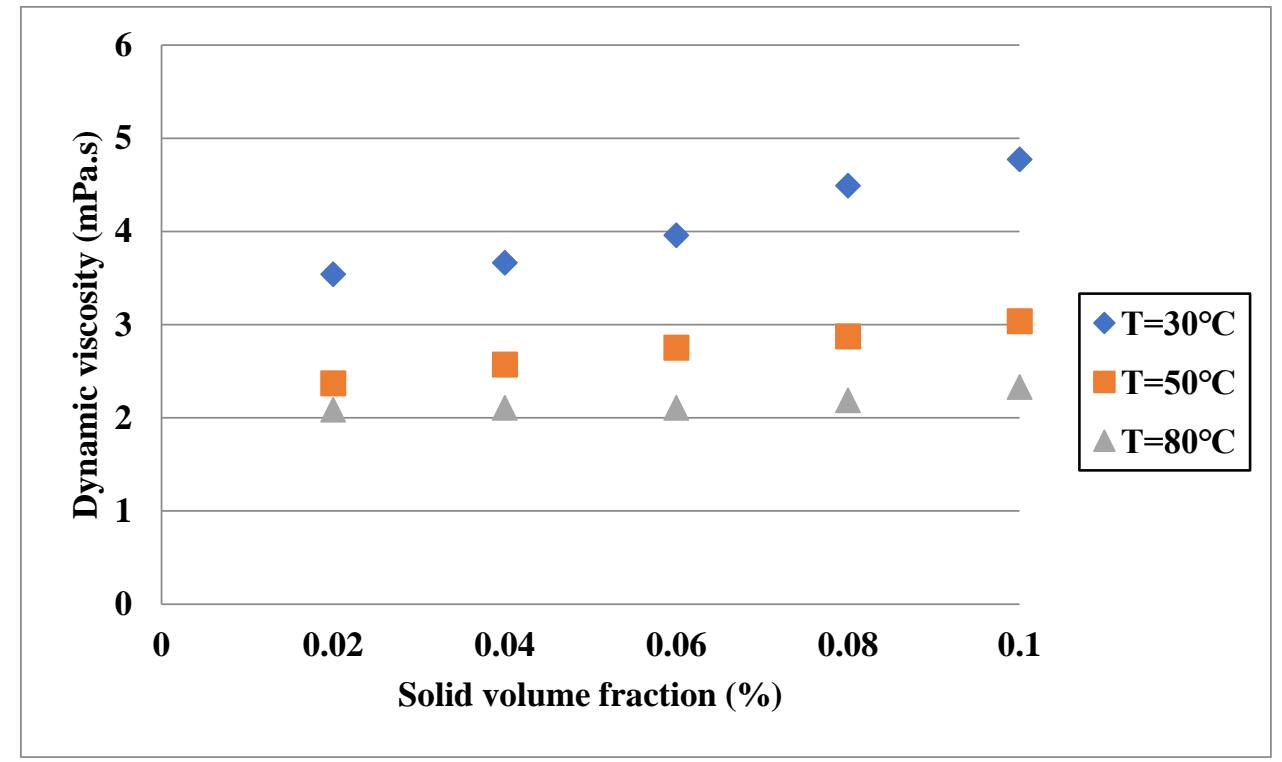

Figure 8. Effect of volume concentration on $\mathrm{DV}$ of $\mathrm{TiO}_{2}-\mathrm{Al}_{2} \mathrm{O}_{3}$ / water-EG. Adapted from Ref. [81].

Aside from the hybrid nanofluids with two dissimilar materials, the DV of the ones with three dissimilar materials has been investigated by some researchers. For instance, Sahoo [83] performed a study on the DV of a ternary hybrid nanofluid. This nanofluid was composed of water as the base fluid and $\mathrm{Al}_{2} \mathrm{O}_{3}, \mathrm{TiO}_{2}$ and $\mathrm{SiC}$ nanoparticles. Similar to the conventional hybrid nanofluids, it was observed that the increase in the temperature caused a reduction in the DV while an increase in solid fraction led to higher DV values. In another work [84], the $\mathrm{DV}$ of $\mathrm{Al}_{2} \mathrm{O}_{3}-\mathrm{CuO}-\mathrm{TiO}_{2} /$ water was measured for temperature and solid fraction ranges of $35-50{ }^{\circ} \mathrm{C}$ and $0.01-0.1 \%$, respectively. It was noticed that by increasing the temperature from 35 to $50{ }^{\circ} \mathrm{C}$, the DV decreased by up to $23.64 \%$. In addition, a comparison between the ternary hybrid nanofluid and $\mathrm{Al}_{2} \mathrm{O}_{3}-\mathrm{CuO} /$ water and $\mathrm{Al}_{2} \mathrm{O}_{3}-\mathrm{TiO}_{2}$ /water revealed a higher DV of the ternary nanofluid.

Due to the non-Newtonian behavior of some of the nanofluids $[85,86]$, it is crucial to consider the shear rate in measuring and reporting the DV. Contrary to the Newtonian fluids, shear rate affects the DV of non-Newtonian fluids. In Newtonian fluids, the DV is influenced by the stress and the behavior of the fluid under the force can change to more solid or more liquid. In order to find the impacts of stress on the DV of these types of fluids, 
different shear rates can be applied in the measurement procedure. Esfe [87] measured the $\mathrm{DV}$ of MgO-MWCNT/5W50 oil in various solid fractions $(0.05-1 \%)$, temperatures $\left(5-55^{\circ} \mathrm{C}\right.$ and shear rates (665.5-11997 s $\left.{ }^{-1}\right)$. According to their observations, at low temperatures, the DV had relatively high dependency on the shear rate and its value decreased by shear rate; however, at higher temperatures, this dependency diminished. In addition, it was observed that the increase in the VF caused an increase in the DV, while the effect of temperature was the reverse. In another work, the effects of temperature, shear rate and solid fraction on the DV of $\mathrm{SiO}_{2}-\mathrm{MWCNT} / 10 \mathrm{~W} 40$ oil were investigated by Nadooshan et al. [88]. It was observed that the nanofluid had non-Newtonian behavior at all temperatures, but the base fluid had non-Newtonian behavior just at high temperatures. Alirezaie et al. [89] investigated the DV of MWCNT (COOH-Functionalized)- $\mathrm{MgO}$ /engine oil in a temperature range of $25-50{ }^{\circ} \mathrm{C}$ and a shear rate of $670-8700 \mathrm{~s}^{-1}$. They found that the nanofluid showed relatively non-Newtonian behavior; however, at high temperatures, it became Newtonian. Similar to previous nanofluids, the DV increases with the increase in the solid fraction. Kazemi et al. [90] investigated the DV of graphene- $\mathrm{SiO}_{2} /$ water at different shear rates and found that the nanofluid was non-Newtonian. As shown in Figure 9, the DV of the nanofluid increased by increasing the solid fraction and reducing the shear rate. Hybrid nanofluids with binary base fluids may show non-Newtonian behavior. As an example, Bahrami et al. [91] investigated the DV of $\mathrm{Fe}-\mathrm{CuO} /$ water-EG in different mixture ratios of the base fluid, temperatures, shear rates and solid fractions. They found that the nanofluid showed Newtonian behavior at low solid fractions while it became non-Newtonian at high concentrations.

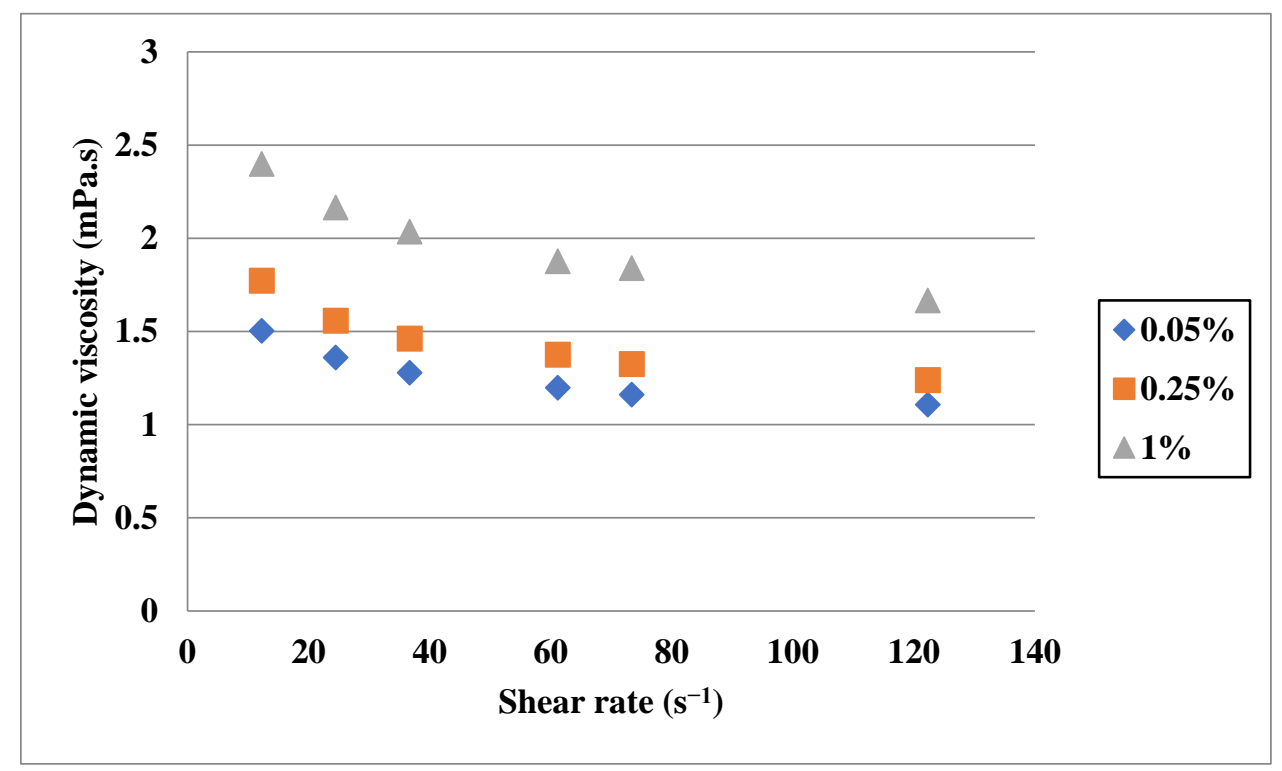

Figure 9. Effect of shear rate on the DV of graphene- $\mathrm{SiO}_{2} /$ water at a temperature of $25^{\circ} \mathrm{C}$. Adapted from Ref. [90].

In Table 5, the main findings of the works on the DV of hybrid nanofluids are provided.

\section{Proposed Models for Dynamic Viscosity}

Similar to TC and SH, there are several models for the DV of hybrid nanofluids by using correlations, ANNs, etc. For instance, in a study by Motahari et al. [76] regarding the temperature of solid volume, a correlation was provided for the DV ratio of MWCNT$\mathrm{SiO}_{2} / 20 \mathrm{~W} 50$ oil with an average deviation of $1.75 \%$. Asadi et al. [72] proposed a simple model for DV considering temperature and solid fraction of MWCNT-MgO-SAE50. In the suggested correlation, the maximum error was around $8 \%$. Urmin et al. [81] proposed a correlation in terms of solid fraction and temperature for the DV of $\mathrm{TiO}_{2}-\mathrm{Al}_{2} \mathrm{O}_{3} /$ water-EG and found that the maximum deviation of the model was $12.7 \%$. In another study [72], a 
correlation was suggested for the DV ratio of $\mathrm{ZnO}-\mathrm{Ag}$ / water nanofluid regarding the VF of solid particles. In the proposed correlation, a polynomial of the third degree was used, and the deviation margin of the obtained model was $1.8 \%$. Models based on correlations are employable for ternary hybrid nanofluids. As an example, Sahoo et al. [84] used a correlation in terms of solid fraction and temperature to suggest a model for the DV of $\mathrm{Al}_{2} \mathrm{O}_{3}-\mathrm{CuO}-\mathrm{TiO}_{2} /$ water. The maximum deviation of their correlation for estimating the DV of the nanofluid was $1.5 \%$. The models based on the correlation can be improved in terms of comprehensiveness by using more variables as inputs. Since the mixture ratio of the nanomaterials can affect the DV of hybrid nanofluids, similar to the TC, considering it as one of the variables would lead to improvement in the comprehensiveness of the models. For instance, Dalkıliç et al. [79] used the ratio of graphite weight to silica weight in addition to the temperature and solid fraction to provide a model for the $\mathrm{DV}$ of $\mathrm{SiO}_{2}$-graphite/water for different mixture ratios of the solid materials. The average deviation of the model by using the mentioned variables as input was $6.75 \%$.

Table 5. Findings of the works on the DV of hybrid nanofluids.

\begin{tabular}{|c|c|c|c|}
\hline Reference & Nanostructures & Base Fluid & Important Findings \\
\hline Asadi et al. [72] & MWCNT-MgO & SAE50 oil & $\begin{array}{l}\text { Up to } 65 \% \text { increase in DV at temperature of } \\
40{ }^{\circ} \mathrm{C} \text { and solid fraction of } 2 \% \text {. }\end{array}$ \\
\hline Alarifi et al. [73] & $\mathrm{TiO}_{2}-\mathrm{MWCNT}$ & 5W50 oil & $\begin{array}{l}\text { Up to } 42 \% \text { increase in DV at temperature of } \\
50{ }^{\circ} \mathrm{C} \text { and solid fraction of } 2 \% \text {. }\end{array}$ \\
\hline Asadi et al. [75] & $\mathrm{CuO}-\mathrm{TiO}_{2}$ & Water & $\begin{array}{l}\text { Increase in the DV by increase } \\
\text { in the solid fraction. }\end{array}$ \\
\hline Goodarzi et al. [74] & ZnO-MWCNT & SAE $10 W 40$ & $\begin{array}{l}\text { Up to around } 100 \% \text { increase } \\
\text { in the DV was observed. }\end{array}$ \\
\hline Senniangiri et al. [77] & Gr-NiO & Coconut oil & $\begin{array}{c}28.49 \% \text { enhancement in DV at temperature } \\
\text { and mass fraction of } 120{ }^{\circ} \mathrm{C} \text { and } \\
0.5 \% \text {, respectively. }\end{array}$ \\
\hline Esfe [87] & MgO-MWCNT & 5W50 oil & $\begin{array}{l}\text { Dependency of viscosity on shear rate } \\
\text { decreased at higher temperatures. }\end{array}$ \\
\hline Dalkılıç et al. [79] & $\mathrm{SiO}_{2}$-graphite & Water & Up to $36.12 \%$ increase in DV in VF of $2 \%$. \\
\hline Kazemi et al. [90] & graphene-SiO 2 & Water & $\begin{array}{l}\text { Increase in the shear rate } \\
\text { caused reduction in DV. }\end{array}$ \\
\hline Ma et al. [80] & $\begin{array}{l}\mathrm{Al}_{2} \mathrm{O}_{3}-\mathrm{TiO}_{2} \text { and } \\
\mathrm{Al}_{2} \mathrm{O}_{3}-\mathrm{CuO}\end{array}$ & Water & $\begin{array}{l}\text { Increase in the surfactant concentration led to } \\
\text { an increase in the DV. }\end{array}$ \\
\hline Motahari et al. [76] & MWCNT-SiO 2 & 20W50 oil & $\begin{array}{c}\text { Up to } 177 \% \text { increase in the DV was observed } \\
\text { at a solid fraction of } 1 \% .\end{array}$ \\
\hline Ruhani et al. [71] & $\mathrm{ZnO}-\mathrm{Ag}$ & Water & $\begin{array}{c}\text { Relative DV of the nanofluid was around } \\
1.75 \text { at a solid fraction of } 2 \% \text { and } \\
\text { temperature of } 25^{\circ} \mathrm{C} \text {. }\end{array}$ \\
\hline Alirezaie et al. [89] & $\begin{array}{l}\text { MWCNT (COOH- } \\
\text { Functionalized)-MgO }\end{array}$ & Engine oil & $\begin{array}{l}\text { At low temperatures, the behavior of the } \\
\text { nanofluid was non-Newtonian; however, it } \\
\text { becomes Newtonian at high temperatures. }\end{array}$ \\
\hline Urmi et al. [81] & $\mathrm{TiO}_{2}-\mathrm{Al}_{2} \mathrm{O}_{3}$ & Water-EG & $\begin{array}{l}\text { Up to } 161.8 \% \text { enhancement in the relative DV } \\
\text { of hybrid nanofluid. }\end{array}$ \\
\hline Nadooshan et al. [88] & $\mathrm{SiO}_{2}-\mathrm{MWCNT}$ & $10 \mathrm{~W} 40$ & $\begin{array}{l}\text { DV increased by an increase in the } \\
\text { solid fraction. }\end{array}$ \\
\hline Toghraie et al. [86] & $\mathrm{WO}_{3}-\mathrm{MWCNT}$ & Engine oil & $\begin{array}{l}\text { Reduction in the DV of nanofluid by } \\
\text { increasing the temperature. }\end{array}$ \\
\hline Kumar et al. [82] & $\mathrm{Al}_{2} \mathrm{O}_{3}-\mathrm{CuO}$ & $\begin{array}{l}\text { EG-water and } \\
\text { PG-water }\end{array}$ & $\begin{array}{l}\text { Increase in DV of hybrid nanofluid with } \\
\text { solid fraction increase. }\end{array}$ \\
\hline
\end{tabular}


Table 5. Cont.

\begin{tabular}{|c|c|c|c|}
\hline Reference & Nanostructures & Base Fluid & Important Findings \\
\hline Ghaffarkhah et al. [78] & Different materials & Transformer oil & $\begin{array}{l}\text { Effect of the nanostructure material on the } \\
\text { maximum enhancement of } \\
\text { the DV was very low. }\end{array}$ \\
\hline Sahoo [83] & $\mathrm{Al}_{2} \mathrm{O}_{3}, \mathrm{TiO}_{2}$ and $\mathrm{SiC}$ & Water & $\begin{array}{l}\text { Increase in DV by temperature reduction and } \\
\text { solid fraction increase. }\end{array}$ \\
\hline Sahoo et al. [84] & $\mathrm{Al}_{2} \mathrm{O}_{3}, \mathrm{TiO}_{2}$ and $\mathrm{CuO}$ & Water & $\begin{array}{l}\text { Up to } 23.64 \% \text { reduction in DV of the } \\
\text { nanofluid by increasing temperature } \\
\text { from } 35 \text { to } 50^{\circ} \mathrm{C} \text {. }\end{array}$ \\
\hline Bahrami et al. [91] & $\mathrm{Fe}-\mathrm{CuO}$ & Water-EG & $\begin{array}{c}\text { The nanofluid showed Newtonian behavior } \\
\text { at low concentrations while it was } \\
\text { non-Newtonian at high solid fractions. }\end{array}$ \\
\hline Nabil et al. [50] & $\mathrm{TiO}_{2}-\mathrm{SiO}_{2}$ & Water-EG & $\begin{array}{l}\text { Up to } 80 \% \text { increase in relative DV } \\
\text { at VF of } 3 \% .\end{array}$ \\
\hline Afrand et al. [92] & $\mathrm{SiO}_{2}-\mathrm{MWCNT}$ & SAE40 & $\begin{array}{l}\text { Maximum enhancement of the DV } \\
\text { in VF of } 1 \% \text { was } 37.4 \% \text {. }\end{array}$ \\
\hline Asadi et al. [93] & MWCNT-ZnO & Engine oil & $\begin{array}{l}\text { Up to } 45 \% \text { increase in DV in } \\
\text { solid fraction of } 1 \% .\end{array}$ \\
\hline Huminic et al. [94] & $\mathrm{Fe}-\mathrm{Si}$ & Water & $\begin{array}{l}\text { Increase in DV by increase in the solid } \\
\text { fraction of nanofluid. }\end{array}$ \\
\hline Esfe et al. [95] & MWCNT-SiO 2 & SAE40 & Up to $30.2 \%$ enhancement in DV at VF of $1 \%$ \\
\hline Solatani et al. [96] & MgO-MWCNT & EG & $\begin{array}{l}\text { Up to } 168 \% \text { enhancement in DV by } \\
\text { increasing the solid fraction from } 0.1 \% \text { to } 1 \% \text {. }\end{array}$ \\
\hline Aghaei et al. [97] & CuO-MWCNT & SAE5W50 & $\begin{array}{l}\text { Up to } 35.52 \% \text { increase in the DV by } \\
\text { increasing the solid } \\
\text { fraction from } 0.05 \% \text { to } 1 \% \text {. }\end{array}$ \\
\hline
\end{tabular}

Since the nanofluids may have non-Newtonian behavior, other factors in addition to solid fraction and temperature must be used in the models to have more accurate outputs. For instance, Esfe [87] proposed a correlation for the DV of MgO-MWCNT/5W50 oil nanofluid by considering temperature, solid fraction and shear rate. The proposed model had adequate exactness with a maximum error of $8 \%$. Toghraie et al. [86] suggested two models based on correlation and ANN for the DV of a non-Newtonian hybrid nanofluid composed of $\mathrm{WO}_{3}$ and MWCNT. In their work, various numbers of neurons were tested to find the optimum structure, and it was found that using 39 neurons in the HL led to the best performance. In addition, they found that ANN leads to higher exactness in comparison with the correlation. In another work [89], the DV of MWCNT (COOH-Functionalized)$\mathrm{MgO} /$ engine oil was modeled by considering the shear rate as one of the inputs and employing correlation and ANN. They found that the R-squared of the models by using the ANN was 0.9973 while it was 0.98 in the case of applying correlation.

In addition to correlations, other approaches would be useful for proposing more precise models [77]. For instance, Jamei et al. [98] applied advanced Genetic Programming (GP), which was called Multigene Genetic Programming (MGGP), in addition to Multivariate Linear Regression (MLR) and Gene Expression Programming (GEP) to predict the relative DV of various hybrid nanofluids with Newtonian behavior. The inputs in their models were density and size of the particles, temperature, the DV of the base fluid and the VF of solids. It was noticed that MGGP had the highest exactness with a root mean squared error (RMSE) of 0.05 , followed by GEP and MLR with the values of 0.083 and 0.153 , respectively. Furthermore, according to the sensitivity analysis, they concluded that the solid fraction, temperature and size of particles were the most influential elements in the relative DV of the investigated hybrid nanofluids. In another work conducted 
by Ghaffarkhah et al. [78], various approaches, including the Group Method of Data Handling (GMDH), Support Vector Machine (SVM), Radial Basis Function (RBF) and Multi-layer Perceptron (MLP), coupled with different optimization algorithms were used to model the DV of hybrid nanofluids. Comparing the exactness of the proposed models demonstrates that GMDH outperforms other approaches. Table 6 summarizes the works on the estimation of hybrid nanofluids' DV.

Table 6. Proposed models for the DV of hybrid nanofluids.

\begin{tabular}{|c|c|c|c|c|}
\hline Reference & Nanostructures & Base Fluid & Method & Important Findings \\
\hline Esfe [87] & MgO-MWCNT & $5 \mathrm{~W} 50$ oil & Correlation & The model highest error was $8 \%$. \\
\hline Motahari et al. [76] & MWCNT-SiO 2 & 20W50 oil & Correlation & $\begin{array}{c}\text { The model mean } \\
\text { deviation was } 1.75 \% \text {. }\end{array}$ \\
\hline Alarifi et al. [73] & $\mathrm{TiO}_{2}-\mathrm{MWCNT}$ & 5W50 oil & Correlation & The model highest error was $4 \%$. \\
\hline Ruhani et al. [71] & $\mathrm{ZnO}-\mathrm{Ag}$ & Water & Correlation & $\begin{array}{l}\text { Deviation margin of } \\
\text { the model was } 1.8 \% \text {. }\end{array}$ \\
\hline Goodarzi et al. [74] & ZnO-MWCNT & SAE 10W40 & Correlation & $\begin{array}{c}\text { R-squared of the correlation } \\
\text { was around } 0.997 \text {. }\end{array}$ \\
\hline Asadi et al. [72] & MWCNT-MgO & SAE50 oil & Correlation & The model highest error was $8 \%$. \\
\hline Urmin et al. [81] & $\mathrm{TiO}_{2}-\mathrm{Al}_{2} \mathrm{O}_{3}$ & Water-EG & Correlation & $\begin{array}{l}\text { Maximum deviation of the } \\
\text { model was } 12.7 \% \text {. }\end{array}$ \\
\hline Sahoo et al. [84] & $\mathrm{Al}_{2} \mathrm{O}_{3}, \mathrm{TiO}_{2}$ and $\mathrm{CuO}$ & Water & Correlation & $\begin{array}{l}\text { Maximum deviation of the } \\
\text { model was } 1.5 \% \text {. }\end{array}$ \\
\hline Dalkılıç et al. [79] & $\mathrm{SiO}_{2}$-graphite & Water & Correlation & $\begin{array}{l}\text { Average deviation of } \\
\text { the model was } 6.75 \% \text {. }\end{array}$ \\
\hline Afrand et al. [92] & $\mathrm{SiO}_{2}-\mathrm{MWCNT}$ & SAE40 & Correlation & $\begin{array}{l}\text { Maximum deviation of the } \\
\text { model was } 0.75 \% \text {. }\end{array}$ \\
\hline Toghraie et al. [86] & $\mathrm{WO}_{3}-\mathrm{MWCNT}$ & Engine oil & Correlation and ANN & $\begin{array}{l}\text { R-squared of the models based } \\
\text { on ANN and correlation were } \\
\text { around } 0.9998 \text { and } \\
0.9994, \text { respectively. }\end{array}$ \\
\hline $\begin{array}{l}\text { Ghaffarkhah et al. } \\
\text { [78] }\end{array}$ & Different materials & Transformer oil & $\begin{array}{c}\text { GMDH, SVM, MLP } \\
\text { and RBF with different } \\
\text { optimization methods }\end{array}$ & $\begin{array}{l}\text { GMDH outperforms the other } \\
\text { methods in predicting DV of the } \\
\text { hybrid nanofluids. }\end{array}$ \\
\hline Jamei et al. [98] & Different materials & Different oils & MLR, MGGP and GEP & $\begin{array}{l}\text { Applying MGGP led to the } \\
\text { highest exactness in prediction } \\
\text { of relative DV. }\end{array}$ \\
\hline Alirezaie et al. [89] & $\begin{array}{l}\text { MWCNT (COOH- } \\
\text { Functionalized)- } \\
\text { MgO }\end{array}$ & Engine oil & Correlation and ANN & $\begin{array}{l}\text { R-squared of the ANN and } \\
\text { correlation were } 0.9973 \text { and } \\
0.98 \text {, respectively. }\end{array}$ \\
\hline Sahoo [83] & $\mathrm{Al}_{2} \mathrm{O}_{3}, \mathrm{TiO}_{2}$ and $\mathrm{SiC}$ & Water & Correlation & $\begin{array}{l}\text { R-squared of the model in term } \\
\text { of solid fraction was } 0.9887 \text {. }\end{array}$ \\
\hline Nabil et al. [50] & $\mathrm{TiO}_{2}-\mathrm{SiO}_{2}$ & Water-EG & Correlation & $\begin{array}{l}\text { Maximum deviation of the } \\
\text { model was } 9.5 \% \text {. }\end{array}$ \\
\hline Esfe et al. [95] & MWCNT-SiO 2 & SAE40 & Correlation & $\begin{array}{l}\text { Maximum deviation of the } \\
\text { model was } 1.2 \% \text {. }\end{array}$ \\
\hline Afrand et al. [99] & $\mathrm{MWCNT}_{-\mathrm{SiO}_{2}}$ & AE40 & Correlation and ANN & $\begin{array}{l}\text { The deviation margins of the } \\
\text { correlation and ANN were } 4 \% \\
\text { and } 1.5 \% \text {, respectively. }\end{array}$ \\
\hline Aghaei et al. [97] & CuO-MWCNT & SAE5W50 & Correlation and ANN & $\begin{array}{l}\text { R-squared values were } 0.9998 \\
\text { and } 0.998 \text { in cases of employing } \\
\text { ANN and correlation. }\end{array}$ \\
\hline
\end{tabular}

Using hybrid models have been implemented to numerical solution of nanofluid flow problems. Adapted from Ref. [89] and Ref. [90]. 


\section{Conclusions}

The main challenge in improving the thermal performance of a fluid is to improve the working fluid thermophysical properties. In the present work, the thermophysical properties of the hybrid nanofluids, including thermal conductivity, specific heat and dynamic viscosity, as well as their proposed models, are reviewed. The main findings of the study, regarding the questions provided in the methodology section, can be summarized as follows:

- Temperature and solid fraction significantly influence the characteristics of hybrid nanofluids.

- In addition to the abovementioned factors, nanostructure material, mixture ratio and base fluid affect the features of hybrid nanofluids.

- Dispersion of the hybrid nanostructures can notably improve the TC of hybrid nanofluids, which is more remarkable at higher temperatures.

- The DV of hybrid nanofluids increases with an increase in the solid fraction.

- Some of the hybrid nanofluids show Newtonian behavior, while some others are non-Newtonian. At higher solid fractions, there is more tendency toward nonNewtonian behavior.

- Both simple correlations and intelligent methods are applicable for modeling the properties of hybrid nanofluids.

- The exactness of the models proposed for thermophysical properties of a nanofluid is mainly under the influences of method and input variables.

- Intelligent methods, such as ANNs, are preferred in terms of accuracy compared with the correlation for modeling the properties of hybrid nanofluids.

- The accuracy of the intelligent methods can be modified by applying more proper functions and optimization algorithms.

\section{Future Recommendations}

In this review paper, important thermophysical features of the hybrid nanofluids, including the TC, specific heat and DV, and the proposed models were reviewed. Despite the numerous studies in the relevant fields, some suggestions are provided for upcoming studies to reach more desirable outcomes. First of all, the effects of other factors, such as the shape of nanostructures and type of surfactants, can be considered in future work regarding their influence on the thermal performance of the nanofluidic devices [100]. Furthermore, it would be attractive to propose models with higher comprehensiveness by applying more variables as inputs. The features of the nanostructure are among the variables that can develop the models' applicability. In addition, despite the key role of the mixture ratio of nanomaterials on the thermophysical properties of the hybrid nanofluids, only a few studies have considered this factor for the TC and DV. Future works should consider the mixture ratio with wider ranges for different hybrid nanofluids. In addition, the effect of mixture ratio on the $\mathrm{SH}$ of hybrid nanofluids should be considered in future works.

Furthermore, different data-driven methods, such as SVM, can be used more widely. In addition, novel and efficient optimization algorithms should be used and coupled with data driven approaches to reach the minim deviation in modeling the properties of the hybrid nanofluids.

Author Contributions: Conceptualization, M.M.R. and M.A.N.; methodology, M.M.R., M.A.N. and I.M.; formal analysis, M.M.R. and M.A.N.; investigation, I.M. and M.E.H.A.; writing-original draft preparation, R.A. and A.N.; writing-review and editing, M.E.H.A., M.E.A. and N.M.; supervision, M.E.A.; funding acquisition, I.M. All authors have read and agreed to the published version of the manuscript.

Funding: The authors (Ali, Almuzaiqer and Nuhait) would like to extend their sincere appreciation to the Deanship of Scientific Research at King Saud University for funding this work through the Re-search Group Project No. (RGP-080).

Data Availability Statement: Not applicable. 
Acknowledgments: The authors would like to thank Khaled Younes and Ahmad Moghrabi for their useful comments and help in preparation of the manuscript.

Conflicts of Interest: The authors declare no conflict of interest.

\section{Nomenclature}

$\begin{array}{ll}\text { ANFIS } & \text { Adaptive Neuro-Fuzzy Inference System } \\ \text { ANN } & \text { Artificial Neural Network } \\ \text { CNT } & \text { Carbon Nano Tube } \\ \text { DV } & \text { Dynamic Viscosity } \\ \text { GA } & \text { Genetic Algorithm } \\ \text { GEP } & \text { Gene Expression Programming } \\ \text { GMDH } & \text { Group Method of Data Handling } \\ \text { GP } & \text { Genetic Programming } \\ \text { HL } & \text { Hidden Layer } \\ \text { LGP } & \text { Linear Genetic Programming } \\ \text { LWLR } & \text { Locally Weighted Linear Regression } \\ \text { MLR } & \text { Multilinear Regression } \\ \text { MSE } & \text { Mean Squared Error } \\ \text { MT } & \text { Model Tree } \\ \text { PSO } & \text { Particle Swarm Optimization } \\ \text { RBF } & \text { Radial Basis Function } \\ \text { RMSE } & \text { Root Mean Squared Error } \\ \text { SH } & \text { Specific Heat } \\ \text { SVM } & \text { Support Vector Machine } \\ \text { TC } & \text { Thermal Conductivity } \\ \text { TCR } & \text { Thermal Conductivity Ratio } \\ \text { VF } & \text { Volume Fraction }\end{array}$

\section{References}

1. Sundar, L.S.; Sharma, K.V.; Singh, M.K.; Sousa, A.C.M. Hybrid nanofluids preparation, thermal properties, heat transfer and friction factor-A review. Renew. Sustain. Energy Rev. 2017, 68, 185-198. [CrossRef]

2. Kazemi-Beydokhti, A.; Heris, S.Z.; Jaafari, M.R. Experimental investigation of thermal conductivity of medical nanofluids based on functionalised single-wall carbon nanotube and conjugated cisplatin. Micro Nano Lett. 2015, 10, 241-247. [CrossRef]

3. Du, C.; Nguyen, Q.; Malekahmadi, O.; Mardani, A.; Jokar, Z.; Babadi, E.; D’Orazio, A.; Karimipour, A.; Li, Z.; Bach, Q.V. Thermal conductivity enhancement of nanofluid by adding multiwalled carbon nanotubes: Characterization and numerical modeling patterns. In Mathematical Methods in the Applied Sciences; John Wiley and Sons Ltd.: Hoboken, NJ, USA, 2020.

4. Ghalandari, M.; Maleki, A.; Haghighi, A.; Safdari Shadloo, M.; Alhuyi Nazari, M.; Tlili, I. Applications of nanofluids containing carbon nanotubes in solar energy systems: A review. J. Mol. Liq. 2020, 313, 113476. [CrossRef]

5. Shanbedi, M.; Heris, S.Z.; Amiri, A.; Eshghi, H. Synthesis of water-soluble Fe-decorated multi-walled carbon nanotubes: A study on thermo-physical properties of ferromagnetic nanofluid. J. Taiwan Inst. Chem. Eng. 2016, 60, 547-554. [CrossRef]

6. Kazemi-Beydokhti, A.; Heris, S.Z.; Moghadam, N.; Shariati-Niasar, M.; Hamidi, A.A. Experimental Investigation of Parameters Affecting Nanofluid Effective Thermal Conductivity. Chem. Eng. Commun. 2014, 201, 593-611. [CrossRef]

7. Shanbedi, M.; Zeinali Heris, S.; Maskooki, A. Experimental investigation of stability and thermophysical properties of carbon nanotubes suspension in the presence of different surfactants. J. Therm. Anal. Calorim. 2015, 120, 1193-1201. [CrossRef]

8. Shanbedi, M.; Amiri, A.; Zeinali Heris, S.; Eshghi, H.; Yarmand, H. Effect of magnetic field on thermo-physical and hydrodynamic properties of different metals-decorated multi-walled carbon nanotubes-based water coolants in a closed conduit. J. Therm. Anal. Calorim. 2017, 131, 1089-1106. [CrossRef]

9. Selimefendigil, F.; Öztop, H.F. Identification of pulsating flow effects with CNT nanoparticles on the performance enhancements of thermoelectric generator (TEG) module in renewable energy applications. Renew. Energy 2020, 162, 1076-1086. [CrossRef]

10. Said, Z.; Rahman, S.M.A.; El Haj Assad, M.; Alami, A.H. Heat transfer enhancement and life cycle analysis of a Shell-and-Tube Heat Exchanger using stable $\mathrm{CuO} /$ water nanofluid. Sustain. Energy Technol. Assess. 2019, 31, 306-317. [CrossRef]

11. Samira, P.; Saeed, Z.H.; Motahare, S.; Mostafa, K. Pressure drop and thermal performance of CuO/ethylene glycol (60\%)-water $(40 \%)$ nanofluid in car radiator. Korean J. Chem. Eng. 2014, 32, 609-616. [CrossRef]

12. Sajid, M.U.; Ali, H.M. Thermal conductivity of hybrid nanofluids: A critical review. Int. J. Heat Mass Transf. 2018, 126, 211-234. [CrossRef]

13. Sarkar, J.; Ghosh, P.; Adil, A. A review on hybrid nanofluids: Recent research, development and applications. Renew. Sustain. Energy Rev. 2015, 43, 164-177. [CrossRef] 
14. Hemmat Esfe, M.; Esfandeh, S.; Kamyab, M.H. History and introduction. In Hybrid Nanofluids for Convection Heat Transfer; Academic Press: Cambridge, MA, USA, 2020; pp. 1-48. [CrossRef]

15. Wei Xian, H.; Azwadi Che Sidik, N.; Rahmah Aid, S.; Lit Ken, T.; Asako, Y.; Malaysia Kuala Lumpur, T.; Sultan Yahya Petra, J.; Lumpur, K. Review on Preparation Techniques, Properties and Performance of Hybrid Nanofluid in Recent Engineering Applications. J. Adv. Res. Fluid Mech. Therm. Sci. J. Homepage 2018, 45, 1-13.

16. Das, P.K. A review based on the effect and mechanism of thermal conductivity of normal nanofluids and hybrid nanofluids. J. Mol. Liq. 2017, 240, 420-446. [CrossRef]

17. Yıldız, Ç.; Arıcı, M.; Karabay, H. Comparison of a theoretical and experimental thermal conductivity model on the heat transfer performance of $\mathrm{Al}_{2} \mathrm{O}_{3}-\mathrm{SiO}_{2}$ / water hybrid-nanofluid. Int. J. Heat Mass Transf. 2019, 140, 598-605. [CrossRef]

18. Selimefendigil, F.; Öztop, H.F. Analysis of hybrid nanofluid and surface corrugation in the laminar convective flow through an encapsulated PCM filled vertical cylinder and POD-based modeling. Int. J. Heat Mass Transf. 2021, 178, 121623. [CrossRef]

19. Hussein, O.A.; Habib, K.; Muhsan, A.S.; Saidur, R.; Alawi, O.A.; Ibrahim, T.K. Thermal performance enhancement of a flat plate solar collector using hybrid nanofluid. Sol. Energy 2020, 204, 208-222. [CrossRef]

20. Fattahi, A. Numerical simulation of a solar collector equipped with a twisted tape and containing a hybrid nanofluid. Sustain. Energy Technol. Assess. 2021, 45, 101200. [CrossRef]

21. Asokan, N.; Gunnasegaran, P.; Vicki Wanatasanappan, V. Experimental investigation on the thermal performance of compact heat exchanger and the rheological properties of low concentration mono and hybrid nanofluids containing $\mathrm{Al}_{2} \mathrm{O}_{3}$ and $\mathrm{CuO}$ nanoparticles. Therm. Sci. Eng. Prog. 2020, 20, 100727. [CrossRef]

22. Pandya, N.S.; Desai, A.N.; Kumar Tiwari, A.; Said, Z. Influence of the geometrical parameters and particle concentration levels of hybrid nanofluid on the thermal performance of axial grooved heat pipe. Therm. Sci. Eng. Prog. 2021, 21, 100762. [CrossRef]

23. Zufar, M.; Gunnasegaran, P.; Kumar, H.M.; Ng, K.C. Numerical and experimental investigations of hybrid nanofluids on pulsating heat pipe performance. Int. J. Heat Mass Transf. 2020, 146, 118887. [CrossRef]

24. Akhgar, A.; Toghraie, D.; Sina, N.; Afrand, M. Developing dissimilar artificial neural networks (ANNs) to prediction the thermal conductivity of MWCNT-TiO $/$ /Water-ethylene glycol hybrid nanofluid. Powder Technol. 2019, 355, 602-610. [CrossRef]

25. Aparna, Z.; Michael, M.; Pabi, S.K.; Ghosh, S. Thermal conductivity of aqueous $\mathrm{Al}_{2} \mathrm{O}_{3} / \mathrm{Ag}$ hybrid nanofluid at different temperatures and volume concentrations: An experimental investigation and development of new correlation function. Powder Technol. 2019, 343, 714-722. [CrossRef]

26. Bakhtiari, R.; Kamkari, B.; Afrand, M.; Abdollahi, A. Preparation of stable $\mathrm{TiO}_{2}$-Graphene/Water hybrid nanofluids and development of a new correlation for thermal conductivity. Powder Technol. 2021, 385, 466-477. [CrossRef]

27. Hemmat Esfe, M.; Esfandeh, S.; Rejvani, M. Modeling of thermal conductivity of $\mathrm{MWCNT}^{-S_{i O}}$ (30:70\%)/EG hybrid nanofluid, sensitivity analyzing and cost performance for industrial applications. J. Therm. Anal. Calorim. 2018, 131, 1437-1447. [CrossRef]

28. Esfahani, N.N.; Toghraie, D.; Afrand, M. A new correlation for predicting the thermal conductivity of $\mathrm{ZnO}-\mathrm{Ag}(50 \%-50 \%) / \mathrm{water}$ hybrid nanofluid: An experimental study. Powder Technol. 2018, 323, 367-373. [CrossRef]

29. Taherialekouhi, R.; Rasouli, S.; Khosravi, A. An experimental study on stability and thermal conductivity of water-graphene oxide/aluminum oxide nanoparticles as a cooling hybrid nanofluid. Int. J. Heat Mass Transf. 2019, 145, 118751. [CrossRef]

30. Singh, J.; Kumar, R.; Gupta, M.; Kumar, H. Thermal conductivity analysis of GO-CuO/DW hybrid nanofluid. In Materials Today: Proceedings; Elsevier Ltd.: Amsterdam, The Netherlands, 2020; Volume 28, pp. 1714-1718.

31. Esfe, M.H.; Rejvani, M.; Karimpour, R.; Abbasian Arani, A.A. Estimation of thermal conductivity of ethylene glycol-based nanofluid with hybrid suspensions of SWCNT- $\mathrm{Al}_{2} \mathrm{O}_{3}$ nanoparticles by correlation and ANN methods using experimental data. $J$. Therm. Anal. Calorim. 2017, 128, 1359-1371. [CrossRef]

32. Toghraie, D.; Chaharsoghi, V.A.; Afrand, M. Measurement of thermal conductivity of ZnO-TiO2/EG hybrid nanofluid. J. Therm. Anal. Calorim. 2016, 125, 527-535. [CrossRef]

33. Zadkhast, M.; Toghraie, D.; Karimipour, A. Developing a new correlation to estimate the thermal conductivity of MWCNT$\mathrm{CuO} /$ water hybrid nanofluid via an experimental investigation. J. Therm. Anal. Calorim. 2017, 129, 859-867. [CrossRef]

34. Esfe, M.H.; Esfandeh, S.; Amiri, M.K.; Afrand, M. A novel applicable experimental study on the thermal behavior of SWCNTs(60\%)-MgO(40\%)/EG hybrid nanofluid by focusing on the thermal conductivity. Powder Technol. 2019, 342, 998-1007. [CrossRef]

35. Hemmat Esfe, M.; Behbahani, P.M.; Arani, A.A.A.; Sarlak, M.R. Thermal conductivity enhancement of $\mathrm{SiO}_{2}-\mathrm{MWCNT}(85: 15 \%)-$ EG hybrid nanofluids: ANN designing, experimental investigation, cost performance and sensitivity analysis. J. Therm. Anal. Calorim. 2017, 128, 249-258. [CrossRef]

36. Soltani, F.; Toghraie, D.; Karimipour, A. Experimental measurements of thermal conductivity of engine oil-based hybrid and mono nanofluids with tungsten oxide $\left(\mathrm{WO}_{3}\right)$ and MWCNTs inclusions. Powder Technol. 2020, 371, 37-44. [CrossRef]

37. Kazemi, I.; Sefid, M.; Afrand, M. Improving the thermal conductivity of water by adding mono \& hybrid nano-additives containing graphene and silica: A comparative experimental study. Int. Commun. Heat Mass Transf. 2020, 116, 104648. [CrossRef]

38. Hemmat Esfe, M.; Abbasian Arani, A.A.; Shafiei Badi, R.; Rejvani, M. ANN modeling, cost performance and sensitivity analyzing of thermal conductivity of DWCNT-SiO 2 /EG hybrid nanofluid for higher heat transfer. J. Therm. Anal. Calorim. 2018, 131, 2381-2393. [CrossRef] 
39. Pourrajab, R.; Noghrehabadi, A.; Behbahani, M.; Hajidavalloo, E. An efficient enhancement in thermal conductivity of waterbased hybrid nanofluid containing MWCNTs-COOH and Ag nanoparticles: Experimental study. J. Therm. Anal. Calorim. 2021, 143, 3331-3343. [CrossRef]

40. Van Trinh, P.; Anh, N.N.; Hong, N.T.; Hong, P.N.; Minh, P.N.; Thang, B.H. Experimental study on the thermal conductivity of ethylene glycol-based nanofluid containing Gr-CNT hybrid material. J. Mol. Liq. 2018, 269, 344-353. [CrossRef]

41. Dalkılıç, A.S.; Yalçın, G.; Küçükyıldırım, B.O.; Öztuna, S.; Akdoğan Eker, A.; Jumpholkul, C.; Nakkaew, S.; Wongwises, S. Experimental study on the thermal conductivity of water-based $\mathrm{CNT}-\mathrm{SiO}_{2}$ hybrid nanofluids. Int. Commun. Heat Mass Transf. 2018, 99, 18-25. [CrossRef]

42. Tiwari, A.K.; Pandya, N.S.; Said, Z.; Öztop, H.F.; Abu-Hamdeh, N. 4 S consideration (synthesis, sonication, surfactant, stability) for the thermal conductivity of $\mathrm{CeO}_{2}$ with MWCNT and water based hybrid nanofluid: An experimental assessment. Colloids Surf. A Physicochem. Eng. Asp. 2021, 610, 125918. [CrossRef]

43. Wole-Osho, I.; Okonkwo, E.C.; Adun, H.; Kavaz, D.; Abbasoglu, S. An intelligent approach to predicting the effect of nanoparticle mixture ratio, concentration and temperature on thermal conductivity of hybrid nanofluids. J. Therm. Anal. Calorim. 2020, 144, 671-688. [CrossRef]

44. Kakavandi, A.; Akbari, M. Experimental investigation of thermal conductivity of nanofluids containing of hybrid nanoparticles suspended in binary base fluids and propose a new correlation. Int. J. Heat Mass Transf. 2018, 124, 742-751. [CrossRef]

45. Rostamian, S.H.; Biglari, M.; Saedodin, S.; Hemmat Esfe, M. An inspection of thermal conductivity of CuO-SWCNTs hybrid nanofluid versus temperature and concentration using experimental data, ANN modeling and new correlation. J. Mol. Liq. 2017, 231, 364-369. [CrossRef]

46. Akhgar, A.; Toghraie, D. An experimental study on the stability and thermal conductivity of water-ethylene glycol/TiO ${ }_{2}$ MWCNTs hybrid nanofluid: Developing a new correlation. Powder Technol. 2018, 338, 806-818. [CrossRef]

47. Leong, K.Y.; Razali, I.; Ku Ahmad, K.Z.; Ong, H.C.; Ghazali, M.J.; Abdul Rahman, M.R. Thermal conductivity of an ethylene glycol/water-based nanofluid with copper-titanium dioxide nanoparticles: An experimental approach. Int. Commun. Heat Mass Transf. 2018, 90, 23-28. [CrossRef]

48. Hemmat Esfe, M.; Wongwises, S.; Naderi, A.; Asadi, A.; Safaei, M.R.; Rostamian, H.; Dahari, M.; Karimipour, A. Thermal conductivity of $\mathrm{Cu} / \mathrm{TiO}_{2}$-water/EG hybrid nanofluid: Experimental data and modeling using artificial neural network and correlation. Int. Commun. Heat Mass Transf. 2015, 66, 100-104. [CrossRef]

49. Hemmat Esfe, M.; Abbasian Arani, A.A.; Firouzi, M. Empirical study and model development of thermal conductivity improvement and assessment of cost and sensitivity of EG-water based SWCNT-ZnO (30\%:70\%) hybrid nanofluid. J. Mol. Liq. 2017, 244, 252-261. [CrossRef]

50. Nabil, M.F.; Azmi, W.H.; Abdul Hamid, K.; Mamat, R.; Hagos, F.Y. An experimental study on the thermal conductivity and dynamic viscosity of $\mathrm{TiO}_{2}-\mathrm{SiO}_{2}$ nanofluids in water: Ethylene glycol mixture. Int. Commun. Heat Mass Transf. 2017, 86, 181-189. [CrossRef]

51. Rostami, S.; Nadooshan, A.A.; Raisi, A.; Bayareh, M. Modeling the thermal conductivity ratio of an antifreeze-based hybrid nanofluid containing graphene oxide and copper oxide for using in thermal systems. J. Mater. Res. Technol. 2021, 11, $2294-2304$. [CrossRef]

52. Hemmat Esfe, M.; Kiannejad Amiri, M.; Alirezaie, A. Thermal conductivity of a hybrid nanofluid: A new economic strategy and model. J. Therm. Anal. Calorim. 2018, 134, 1113-1122. [CrossRef]

53. Cakmak, N.K.; Said, Z.; Sundar, L.S.; Ali, Z.M.; Tiwari, A.K. Preparation, characterization, stability, and thermal conductivity of rGO-Fe ${ }_{3} \mathrm{O}_{4}-\mathrm{TiO}_{2}$ hybrid nanofluid: An experimental study. Powder Technol. 2020, 372, 235-245. [CrossRef]

54. Boroomandpour, A.; Toghraie, D.; Hashemian, M. A comprehensive experimental investigation of thermal conductivity of a ternary hybrid nanofluid containing MWCNTs-titania-zinc oxide/water-ethylene glycol (80:20) as well as binary and mono nanofluids. Synth. Met. 2020, 268, 116501. [CrossRef]

55. Moghadam, I.P.; Afrand, M.; Hamad, S.M.; Barzinjy, A.A.; Talebizadehsardari, P. Curve-fitting on experimental data for predicting the thermal-conductivity of a new generated hybrid nanofluid of graphene oxide-titanium oxide/water. Phys. A Stat. Mech. Its Appl. 2020, 548, 122140. [CrossRef]

56. Moradi, A.; Zareh, M.; Afrand, M.; Khayat, M. Effects of temperature and volume concentration on thermal conductivity of $\mathrm{TiO}_{2}$-MWCNTs (70-30)/EG-water hybrid nano-fluid. Powder Technol. 2020, 362, 578-585. [CrossRef]

57. Vafaei, M.; Afrand, M.; Sina, N.; Kalbasi, R.; Sourani, F.; Teimouri, H. Evaluation of thermal conductivity of MgO-MWCNTs/EG hybrid nanofluids based on experimental data by selecting optimal artificial neural networks. Phys. E Low-Dimens. Syst. Nanostruct. 2017, 85, 90-96. [CrossRef]

58. Safaei, M.R.; Hajizadeh, A.; Afrand, M.; Qi, C.; Yarmand, H.; Zulkifli, N.W.B.M. Evaluating the effect of temperature and concentration on the thermal conductivity of $\mathrm{ZnO}-\mathrm{TiO}_{2} / \mathrm{EG}$ hybrid nanofluid using artificial neural network and curve fitting on experimental data. Phys. A Stat. Mech. Appl. 2019, 519, 209-216. [CrossRef]

59. Alarifi, I.M.; Nguyen, H.M.; Bakhtiyari, A.N.; Asadi, A. Feasibility of ANFIS-PSO and ANFIS-GA models in predicting thermophysical properties of $\mathrm{Al}_{2} \mathrm{O}_{3}$-MWCNT/Oil hybrid nanofluid. Materials 2019, 12, 3628. [CrossRef]

60. Pourrajab, R.; Ahmadianfar, I.; Jamei, M.; Behbahani, M. A meticulous intelligent approach to predict thermal conductivity ratio of hybrid nanofluids for heat transfer applications. J. Therm. Anal. Calorim. 2020, 146, 611-628. [CrossRef] 
61. Jamei, M.; Pourrajab, R.; Ahmadianfar, I.; Noghrehabadi, A. Accurate prediction of thermal conductivity of ethylene glycol-based hybrid nanofluids using artificial intelligence techniques. Int. Commun. Heat Mass Transf. 2020, 116, 104624. [CrossRef]

62. Çolak, A.B.; Yıldız, O.; Bayrak, M.; Tezekici, B.S. Experimental study for predicting the specific heat of water based $\mathrm{Cu}_{-} \mathrm{Al}_{2} \mathrm{O}_{3}$ hybrid nanofluid using artificial neural network and proposing new correlation. Int. J. Energy Res. 2020, 44, 7198-7215. [CrossRef]

63. Mousavi, S.M.; Esmaeilzadeh, F.; Wang, X.P. A detailed investigation on the thermo-physical and rheological behavior of $\mathrm{MgO} / \mathrm{TiO}_{2}$ aqueous dual hybrid nanofluid. J. Mol. Liq. 2019, 282, 323-339. [CrossRef]

64. Gao, Y.; Xi, Y.; Zhenzhong, Y.; Sasmito, A.; Mujumdar, A.; Wang, L. Experimental investigation of specific heat of aqueous graphene oxide $\mathrm{Al}_{2} \mathrm{O}_{3}$ hybrid nanofluid. Therm. Sci. 2019, 25, 381. [CrossRef]

65. Tiwari, A.K.; Pandya, N.S.; Shah, H.; Said, Z. Experimental comparison of specific heat capacity of three different metal oxides with MWCNT/ water-based hybrid nanofluids: Proposing a new correlation. Appl. Nanosci. 2020, 1-11. [CrossRef]

66. Mousavi, S.M.; Esmaeilzadeh, F.; Wang, X.P. Effects of temperature and particles volume concentration on the thermophysical properties and the rheological behavior of $\mathrm{CuO} / \mathrm{MgO} / \mathrm{TiO}_{2}$ aqueous ternary hybrid nanofluid: Experimental investigation. $J$. Therm. Anal. Calorim. 2019, 137, 879-901. [CrossRef]

67. Moldoveanu, G.M.; Minea, A.A. Specific heat experimental tests of simple and hybrid oxide-water nanofluids: Proposing new correlation. J. Mol. Liq. 2019, 279, 299-305. [CrossRef]

68. Alade, I.O.; Abd Rahman, M.A.; Saleh, T.A. Predicting the specific heat capacity of alumina/ethylene glycol nanofluids using support vector regression model optimized with Bayesian algorithm. Sol. Energy 2019, 183, 74-82. [CrossRef]

69. Alade, I.O.; Rahman, M.A.A.; Saleh, T.A. An approach to predict the isobaric specific heat capacity of nitrides/ethylene glycolbased nanofluids using support vector regression. J. Energy Storage 2020, 29, 101313. [CrossRef]

70. Alade, I.O.; Abd Rahman, M.A.; Saleh, T.A. Modeling and prediction of the specific heat capacity of $\mathrm{Al}_{2} \mathrm{O}_{3} /$ water nanofluids using hybrid genetic algorithm/support vector regression model. Nano-Struct. Nano-Obj. 2019, 17, 103-111. [CrossRef]

71. Ruhani, B.; Toghraie, D.; Hekmatifar, M.; Hadian, M. Statistical investigation for developing a new model for rheological behavior of $\mathrm{ZnO}-\mathrm{Ag}(50 \%-50 \%) /$ Water hybrid Newtonian nanofluid using experimental data. Phys. A Stat. Mech. Appl. 2019, 525, 741-751. [CrossRef]

72. Asadi, A.; Asadi, M.; Rezaei, M.; Siahmargoi, M.; Asadi, F. The effect of temperature and solid concentration on dynamic viscosity of MWCNT/MgO (20-80)-SAE50 hybrid nano-lubricant and proposing a new correlation: An experimental study. Int. Commun. Heat Mass Transf. 2016, 78, 48-53. [CrossRef]

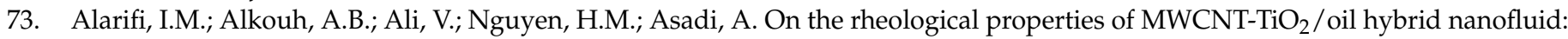
An experimental investigation on the effects of shear rate, temperature, and solid concentration of nanoparticles. Powder Technol. 2019, 355, 157-162. [CrossRef]

74. Goodarzi, M.; Toghraie, D.; Reiszadeh, M.; Afrand, M. Experimental evaluation of dynamic viscosity of ZnO-MWCNTs/engine oil hybrid nanolubricant based on changes in temperature and concentration. J. Therm. Anal. Calorim. 2019, 136, 513-525. [CrossRef]

75. Asadi, A.; Alarifi, I.M.; Foong, L.K. An experimental study on characterization, stability and dynamic viscosity of $\mathrm{CuO}^{-\mathrm{TiO}} \mathrm{O}_{2} / \mathrm{water}$ hybrid nanofluid. J. Mol. Liq. 2020, 307, 112987. [CrossRef]

76. Motahari, K.; Abdollahi Moghaddam, M.; Moradian, M. Experimental investigation and development of new correlation for influences of temperature and concentration on dynamic viscosity of MWCNT-SiO $2(20-80) / 20 W 50$ hybrid nano-lubricant. Chin J. Chem. Eng. 2018, 26, 152-158. [CrossRef]

77. Senniangiri, N.; Bensam Raj, J.; Sunil, J. Effects of Temperature and Particles Concentration on the Dynamic Viscosity of Graphene-NiO/Coconut Oil Hybrid Nanofluid: Experimental Study. Int. J. Nanosci. 2020, 19, 1950016. [CrossRef]

78. Ghaffarkhah, A.; Afrand, M.; Talebkeikhah, M.; Sehat, A.A.; Moraveji, M.K.; Talebkeikhah, F.; Arjmand, M. On evaluation of thermophysical properties of transformer oil-based nanofluids: A comprehensive modeling and experimental study. J. Mol. Liq. 2020, 300, 112249. [CrossRef]

79. Dalkılıç, A.S.; Açıkgöz, Ö.; Küçükyıldırım, B.O.; Eker, A.A.; Lüleci, B.; Jumpholkul, C.; Wongwises, S. Experimental investigation on the viscosity characteristics of water based $\mathrm{SiO}_{2}$-graphite hybrid nanofluids. Int. Commun. Heat Mass Transf. 2018, 97, 30-38. [CrossRef]

80. Ma, M.; Zhai, Y.; Yao, P.; Li, Y.; Wang, H. Effect of surfactant on the rheological behavior and thermophysical properties of hybrid nanofluids. Powder Technol. 2021, 379, 373-383. [CrossRef]

81. Urmi, W.T.; Rahman, M.M.; Hamzah, W.A.W. An experimental investigation on the thermophysical properties of $40 \%$ ethylene glycol based $\mathrm{TiO}_{2}-\mathrm{Al}_{2} \mathrm{O}_{3}$ hybrid nanofluids. Int. Commun. Heat Mass Transf. 2020, 116, 104663. [CrossRef]

82. Kumar, V.; Sahoo, R.R. Viscosity and thermal conductivity comparative study for hybrid nanofluid in binary base fluids. Heat Transf. Asian Res. 2019, 48, 3144-3161. [CrossRef]

83. Sahoo, R.R. Experimental study on the viscosity of hybrid nanofluid and development of a new correlation. Heat Mass Transf. 2020, 56, 3023-3033. [CrossRef]

84. Sahoo, R.R.; Kumar, V. Development of a new correlation to determine the viscosity of ternary hybrid nanofluid. Int. Commun. Heat Mass Transf. 2020, 111, 104451. [CrossRef]

85. Moldoveanu, G.M.; Ibanescu, C.; Danu, M.; Minea, A.A. Viscosity estimation of $\mathrm{Al}_{2} \mathrm{O}_{3}, \mathrm{SiO}_{2}$ nanofluids and their hybrid: An experimental study. J. Mol. Liq. 2018, 253, 188-196. [CrossRef] 
86. Toghraie, D.; Aghahadi, M.H.; Sina, N.; Soltani, F. Application of Artificial Neural Networks (ANNs) for Predicting the Viscosity of Tungsten Oxide ( $\mathrm{WO}_{3}$ )-MWCNTs/Engine Oil Hybrid Nanofluid. Int. J. Thermophys. 2020, 41, 1-17. [CrossRef]

87. Hemmat Esfe, M. On the evaluation of the dynamic viscosity of non-Newtonian oil based nanofluids: Experimental investigation, predicting, and data assessment. J. Therm. Anal. Calorim. 2019, 135, 97-109. [CrossRef]

88. Ahmadi Nadooshan, A.; Hemmat Esfe, M.; Afrand, M. Evaluation of rheological behavior of 10 W40 lubricant containing hybrid nano-material by measuring dynamic viscosity. Phys. E Low-Dimens. Syst. Nanostruct. 2017, 92, 47-54. [CrossRef]

89. Alirezaie, A.; Saedodin, S.; Esfe, M.H.; Rostamian, S.H. Investigation of rheological behavior of MWCNT (COOHfunctionalized)/MgO-Engine oil hybrid nanofluids and modelling the results with artificial neural networks. J. Mol. Liq. 2017, 241, 173-181. [CrossRef]

90. Kazemi, I.; Sefid, M.; Afrand, M. A novel comparative experimental study on rheological behavior of mono \& hybrid nanofluids concerned graphene and silica nano-powders: Characterization, stability and viscosity measurements. Powder Technol. 2020, 366, 216-229. [CrossRef]

91. Bahrami, M.; Akbari, M.; Karimipour, A.; Afrand, M. An experimental study on rheological behavior of hybrid nanofluids made of iron and copper oxide in a binary mixture of water and ethylene glycol: Non-Newtonian behavior. Exp. Therm. Fluid Sci. 2016, 79, 231-237. [CrossRef]

92. Afrand, M.; Nazari Najafabadi, K.; Akbari, M. Effects of temperature and solid volume fraction on viscosity of SiO ${ }_{2-}$ MWCNTs/SAE40 hybrid nanofluid as a coolant and lubricant in heat engines. Appl. Therm. Eng. 2016, 102, 45-54. [CrossRef]

93. Asadi, M.; Asadi, A. Dynamic viscosity of MWCNT/ZnO-engine oil hybrid nanofluid: An experimental investigation and new correlation in different temperatures and solid concentrations. Int. Commun. Heat Mass Transf. 2016, 76, 41-45. [CrossRef]

94. Huminic, G.; Huminic, A.; Fleacă, C.; Dumitrache, F.; Morjan, I. Experimental study on viscosity of water based Fe-Si hybrid nanofluids. J. Mol. Liq. 2021, 321, 114938. [CrossRef]

95. Hemmat Esfe, M.; Afrand, M.; Yan, W.M.; Yarmand, H.; Toghraie, D.; Dahari, M. Effects of temperature and concentration on rheological behavior of MWCNTs/SiO 2 (20-80)-SAE40 hybrid nano-lubricant. Int. Commun. Heat Mass Transf. 2016, 76, 133-138. [CrossRef]

96. Soltani, O.; Akbari, M. Effects of temperature and particles concentration on the dynamic viscosity of MgO-MWCNT/ethylene glycol hybrid nanofluid: Experimental study. Phys. E Low-Dimens. Syst. Nanostruct. 2016, 84, 564-570. [CrossRef]

97. Aghaei, A.; Khorasanizadeh, H.; Sheikhzadeh, G.A. Measurement of the dynamic viscosity of hybrid engine oil-Cuo-MWCNT nanofluid, development of a practical viscosity correlation and utilizing the artificial neural network. Heat Mass Transf. 2018, 54, 151-161. [CrossRef]

98. Jamei, M.; Ahmadianfar, I. A rigorous model for prediction of viscosity of oil-based hybrid nanofluids. Phys. A Stat. Mech. Appl. 2020, 556, 124827. [CrossRef]

99. Afrand, M.; Nazari Najafabadi, K.; Sina, N.; Safaei, M.R.; Kherbeet, A.S.; Wongwises, S.; Dahari, M. Prediction of dynamic viscosity of a hybrid nano-lubricant by an optimal artificial neural network. Int. Commun. Heat Mass Transf. 2016, 76, 209-214. [CrossRef]

100. Zahmatkesh, I.; Sheremet, M.; Yang, L.; Heris, S.Z.; Sharifpur, M.; Meyer, J.P.; Ghalambaz, M.; Wongwises, S.; Jing, D.; Mahian, O. Effect of nanoparticle shape on the performance of thermal systems utilizing nanofluids: A critical review. J. Mol. Liq. 2021, 321, 114430. [CrossRef] 